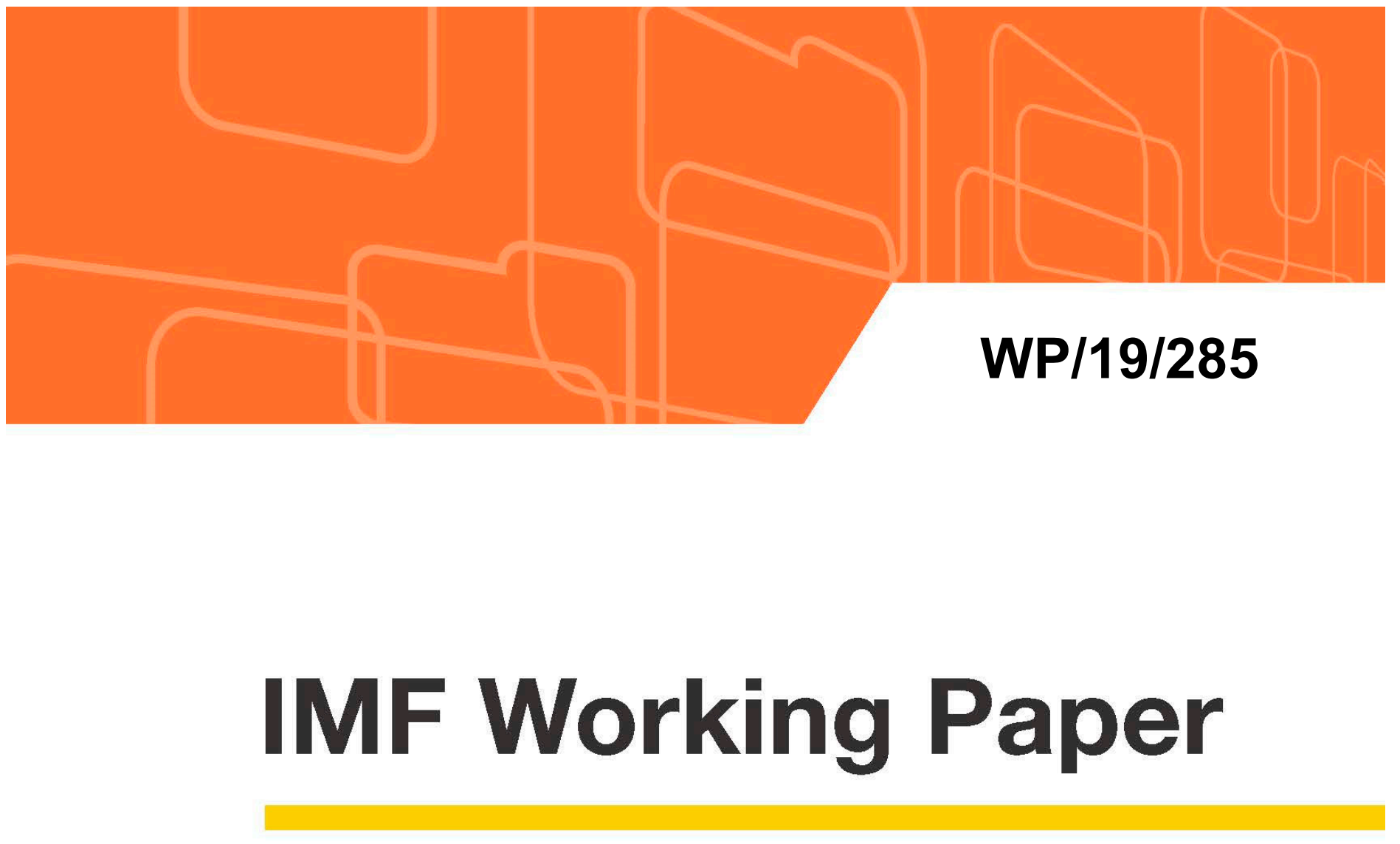

\title{
Money Creation in Fiat and Digital Currency Systems
}

by Marco Gross and Christoph Siebenbrunner

IMF Working Papers describe research in progress by the author(s) and are published to elicit comments and to encourage debate. The views expressed in IMF Working Papers are those of the author(s) and do not necessarily represent the views of the IMF, its Executive Board, or IMF management.

$$
\text { I N T E R N A T | O N A L M O N E T A R Y F U N D }
$$




\title{
IMF Working Paper
}

Monetary and Capital Markets Department

\section{Money Creation in Fiat and Digital Currency Systems * \\ Prepared by Marco Gross ** and Christoph Siebenbrunner ***}

Authorized for distribution by Martin Čihák

December, 2019

IMF Working Papers describe research in progress by the author(s) and are published to elicit comments and to encourage debate. The views expressed in IMF Working Papers are those of the author(s) and do not necessarily represent the views of the IMF, its Executive Board, or IMF management.

\begin{abstract}
To support the understanding that banks' debt issuance means money creation, while centralized nonbank financial institutions' and decentralized bond market intermediary lending does not, the paper aims to convey two related points: First, the notion of money creation as a result of banks' loan creation is compatible with the notion of liquid funding needs in a multi-bank system, in which liquid fund (reserve) transfers across banks happen naturally. Second, interest rate-based monetary policy has a bearing on macroeconomic dynamics precisely due to that multi-bank structure. It would lose its impact in the hypothetical case that only one ("singular") commercial bank would exist. We link our discussion to the emergence and design of central bank digital currencies (CBDC), with a special focus on how loans would be granted in a CBDC world.
\end{abstract}

JEL Classification Numbers: E12, E42, E5

Keywords: Money creation, monetary policy, central bank digital currencies

Authors'email addresses: mgross@imf.org,christoph@siebenbrunner.com

* The paper has benefited from useful discussions with, and comments and suggestions received from, Ulrich Bindseil, Vítor Constâncio, Michal Andrle, Erdem Başçı, Martin Čihák, Alessandro Ferracci, Matheus Grasselli, Mariam El Hamiani Khatat, Tommaso Mancini Griffoli, Alexey Ponomarenko, Tomohiro Tsuruga, the participants of the Conference on New Analytical Tools and Techniques for Economic Policymaking at the OECD (Paris, April 2019), and an IMF-internal seminar in spring 2019. An online companion to this paper is available at www.siebenbrunner.com/moneycreation.

** Monetary and Capital Markets Department, International Monetary Fund

*** Oxford University 
I. Introduction

II. Literature _ 5

III. Definitions __ 8

IV. Balance Sheet Stock and Flow Mechanics under Bank and Nonbank Lending ___ 11

A. Initialization 111

B. Granting and Repayment of Loans to the Private Sector ___ 11

C. Bank versus Nonbank Lending (Example Involving a Sovereign Borrower) ___ 13

D. Securitization _ 15

V. Agent-Based Model Simulation____ 16

VI. Central Bank Digital Currency (CBDC) ___ 21

VII. Conclusions _ 23

Box

1. Definitions__ 9

Figures

1. Literature Review __ 6

2. Initializing the Balance Sheets

3. Loan Creation for the Private Sector 13

4: Nonbank Lending (Primary Sovereign Bond Market Auction) ___ 14

5. Securitization 15

6. Agent-Based Model Structure___ 17

7. Exemplary Simulation Path for Selected Model Variables (Stock Variables) ___ 19

8. Exemplary Simulation Path for Selected Model Variables (Flow Variables) ___ 20

9. Compressing the Banking System Down to a "Singular" One _ 20

10. CBDC-Denoted Lending __ 22

Appendices

I. ABM-Pseudo Code _ 25

II. Endogenous Money and Money Creation_-Useful Quotes from Past Literature ___ 28 


\section{INTRODUCTION}

Three structural features of monetary systems form the starting point for this paper. They include (1) a two-layer structure comprising a private sector agent deposit system with commercial banks, parallel to a commercial bank deposit (reserve) system with central banks, with the two being separate and not allowing transfers between the two, that is, reserves cannot be "lent out" to the private sector (Sheard 2013); (2) the fact that money is created upon the creation of bank loans (Werner 2014/16), while repayment implies money destruction, both of which are an accounting reality, and implying that banks would better not be called "intermediaries"; and (3) the fact that the money stock is endogenously and elastically driven by demand and constrained loosely by regulation. The constraints to the provision of new credit include capital regulation, banks' conditionality on an incremental profit prospect, and, eventually, demand (McLeay et al. 2014) ${ }^{1}$.

Against this background of economic realities, some misled views of how bank lending functions have come about and persisted since long. These include the financial intermediation and the fractional reserve theories of banking, which can be subsumed under a generic "loanable funds" header. They have a micro perspective in falsely interpreting the need for liquid funds as meaning that banks "pass deposits (money) on" when creating loans ${ }^{2}$. This deceptive understanding is, moreover, related to the misleading notion that "savings finance investment," which should rather be phrased as "savings (tautologically) equal investment" (Lavoie 1992, Davidson 1993, Shapiro 2005).

The money creation understanding matters for seeing the role of monetary and macroprudential policy in qualitative and quantitative terms. The intermediation view of banking has implied the loss of relevance of banks and bank credit in macroeconomic models and effectively led to them being dropped in dynamic stochastic general equilibrium (DSGE) models for long. Banks were and still are regularly implemented as if they were nonbank financial intermediaries; which implies the risk of underestimating financial accelerator effects.

Against this combined background, our objective is to highlight that the money creation reality and the notion of "liquid funding needs" are compatible". We sense that the reason for why some skepticism with the money creation view persists may lie in the presence of another economic reality, that is, the need for "liquid funding" with which the money creation view may seem to be incompatible at first sight. Our aim is to emphasize that they are compatible. We follow two routes to that end.

\footnotetext{
${ }^{1}$ More references are provided in Section II.

${ }^{2}$ One may hypothesize about the reasons why the intermediation view has come about: it may be the enhanced complexity of the financial system and significant rise in the number of banking institutions and financial systems at large, in the US, Europe, and elsewhere in the world, throughout the 20th century, which may have led to a loss of system perspective.

${ }^{3}$ We define liquid funding needs as the need for commercial banks to hold reserves at their central bank accounts for the purpose of cross-bank settlement of customer deposits. They can be satisfied through receiving existing deposits (liability side) along with reserves (asset side) from other banks; by borrowing them through money markets from other banks; or by borrowing them from the central bank.
} 
First, we develop a series of balance sheet examples based on double-entry bookkeeping principles. Unlike in the existing related literature, we do not focus on only bank lending (money creation), but also lay out the lending process through centralized nonbank financial institutions as well as decentralized market-based intermediation. After presenting a series of required definitions in Section III, we put forward the balance sheet examples in Section IV.

Second, we develop a simple stock-flow consistent agent-based model (ABM) to illustrate the monetary system dynamics related to the loan and money creation process. The ABM methodology lends itself usefully to implementing the money creation view correctly, as it is built on a stock-flow consistent integrated balance sheet structure; in the case of our model for a population of private sector agents, banks, one central bank, and optionally a sovereign ${ }^{4}$. Based on the model, we highlight that liquid funds are required to back the transfer of newly created, initially illiquid loans and deposits in a multi-bank system. Liquid funding needs do not negate the fact that banks create money "out of nothing."

Based on the ABM, we simulate the hypothetical case of compressing the commercial banking system down to a "singular" one. When considering only one commercial bank and no physical cash, liquid funding (reserve) needs would vanish, liquidity risk cease to exist, and conventional, interest-based monetary policy lose its impact on the economy. The reason is that central bank reserves would not be needed anymore, as all cross-agent transfers would happen on the one commercial bank's electronic deposit pool. It is a very hypothetical, yet insightful in our view, additional insight. We present the ABM and the related simulations in Section V.

Two closely related topics are discussed: they concern bond versus loan finance for governments and the emergence of central bank digital currencies (CBDCs). The two topics are placed in Sections IV and VI, respectively. Concerning CBDCs, we emphasize two points: (1) the emergence of CBDCs should not be seen as a result of central banks' fear of losing their bearing on the economy if physical cash was vanishing, that is, we argue that the monetary policy transmission with and without physical cash is virtually identical; and (2) an important question is how CBDC systems would be designed in terms of credit provision, which, if backed 100 percent by the new digital currency, would resemble the Chicago plan of the 1930s (a topic that we link to in the literature review section as well).

\section{LiterATURE}

Figure 1 presents a series of papers and books spanning the last century, which we have categorized in three groups. These groups include the intermediation, the fractional reserve, and the money creation view. The intermediation view assumes that banks "pass on money" when granting loans, so neither individual banks nor the banking system create money when doing so. The fractional reserve view posits that individual banks do not, but the banking system does, create money when granting loans. If its unrealistic assumption of new loans

\footnotetext{
${ }^{4}$ The flow consistency of the ABM resembles the philosophy of flow of funds (FoF) analysis, albeit at a microagent level instead of a sector level, as done in FoF analyses (Duesenberry 1962, Be Duc and Le Breton 2009, Winkler 2010). Stock-flow consistency is one of the defining criteria of most macro ABMs, with some selected entry points to the related literature being Tesfatsion 2003, Lavoie and Godley 2006, Tesfatsion 2006a/b, Le Baron and Tesfatsion 2008, and Fagiolo and Roventini 2016. Stock-flow consistency is a defining criterion of numerous models in the field of Post-Keynesian economics (Lavoie 2014).
} 
being converted 100 percent to physical cash ${ }^{5}$ and redeposited elsewhere was dropped, it would collapse to the third view, the money creation understanding under which both individual banks as well as the banking system create money when granting loans.

The intermediation versus money creation debate is inherently intertwined with the opposing views of monetarists and Post-Keynesians. Monetarists (led by Friedman) think that the money supply is exogenous, with central banks setting the monetary base and thereby being believed to be acting as though the effective money stock can be controlled through the money multiplier process. Money supply endogeneity, on the other hand, has its origin in Keynes (1930) and was made more explicit by Robinson (1956), Davidson (1978), Kaldor (1982), and Moore (1986). The institutional reality is in line with the latter, as documented in the numerous references, including from central banks, under the money creation view in Figure $1^{6}$.

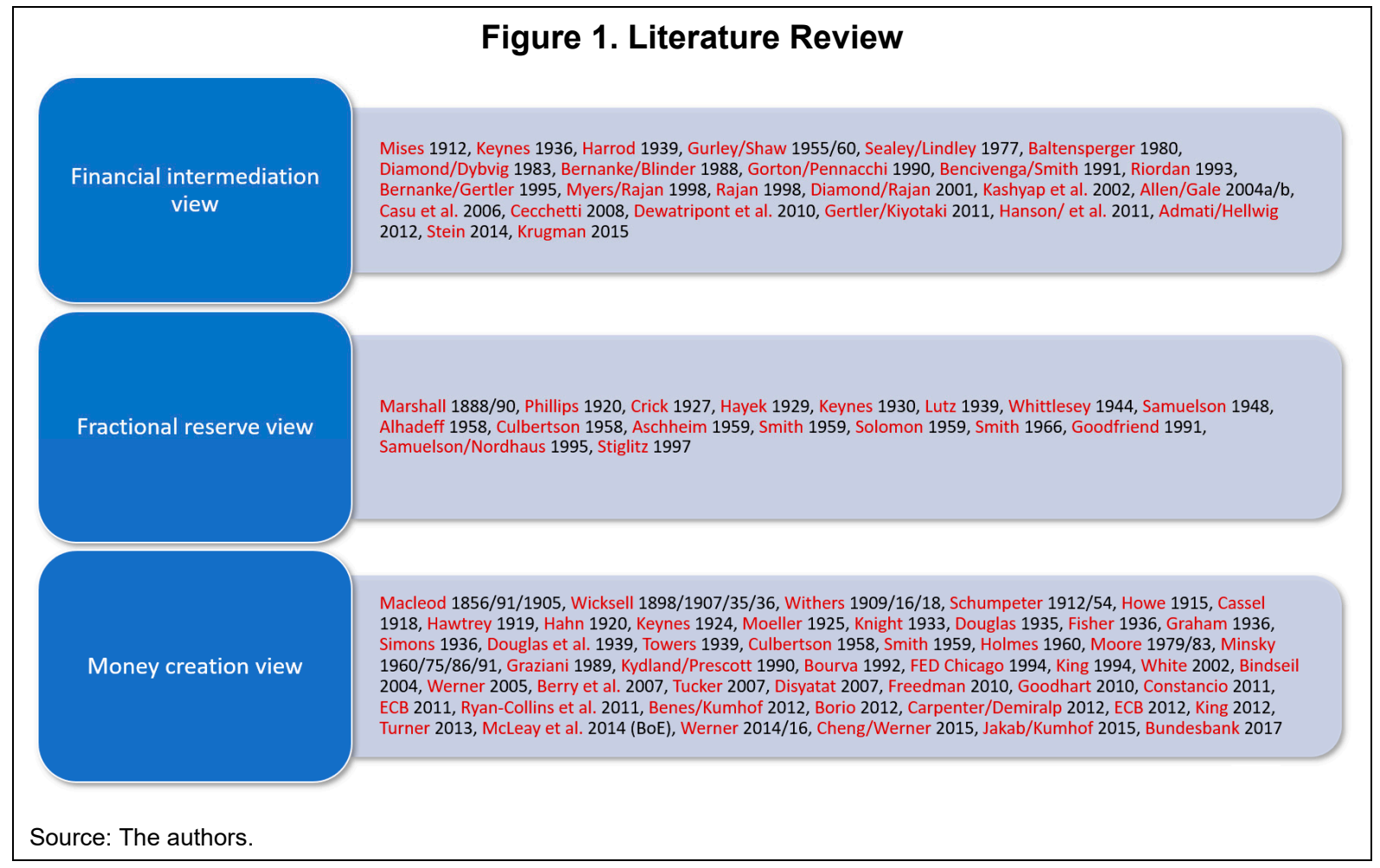

A significant literature stream that was in line with the money creation view had evolved between the end of the 19th century and the Great Depression in 1929. Useful entry points to the early literature include the references by MacLeod, Wicksell and Schumpeter, and others in Figure 1 under the money creation view. Annex II contains a series of quotes that corroborate the money creation and endogenous money view.

\footnotetext{
${ }^{5}$ From now on we refer to physical cash in short as cash.

${ }^{6}$ In addition to seeing the institutional reality, empirical evidence has also been documented, confirming that causality runs from loan volumes to deposits to reserves, that is, the opposite sequence to what monetarist theory suggests. Such evidence can be found in Kaldor (1982) for the United Kingdom, Moore (1983) for the United States, Vera (2001) for Spain, Lavoie (2005) for Canada, and Vymyatnina (2005) for Russia. More references to empirical work of this kind for other countries can be found in these papers.
} 
The money creation view came to the fore (of policy) when the Chicago plan was proposed as a consequence of the Great Depression in 1929. The idea was to deprive commercial banks of their credit and hence money creation ability by introducing a 100 percent reserve system (Knight 1933, Currie 1934, Douglas 1935, Fisher 1936, Graham 1936, Simons 1934/36). The rationale for doing so stemmed from the understanding that the money creation ability of commercial banks was, allegedly, the root cause of the Depression at the time, and of recurrently evolving endogenous business and financial cycle dynamics more generally. The initial Chicago economists' proposal was revived a second time toward the end of the Great Depression period in 1939 (Douglas et al. 1939), when a first post-depression, smaller-scale recession occurred that was conceived to be the result of the FED raising reserve requirements that year. Neither the initial nor the second attempt to implement the 100 percent reserve plan ever succeeded ${ }^{7}$.

The money creation view then became increasingly repressed during the 1940-50s, with the intermediation view fading into mainstream economics instead. This development seems to have started with books and related papers by Gurley and Shaw (1955/56/60). The intermediation view implied that the role of bank credit was significantly diminished, which one may see as the reason why DSGE models largely dropped banks and bank credit toward the end of the 20th century.

After the Global Financial Crisis (GFC) of 2007-09, the money creation view re-surfaced, including through central bank communication. A series of bulletin articles by the Bank of England, more papers from Werner, the Bundesbank, and others (Ryan-Collins et al. 2011, McLeay et al. 2014a/b, Werner 2014a/2016, Deutsche Bundesbank 2017) all aimed at reviving the money creation understanding. In the long intermittent period, a few names that kept being aligned with the money creation view included, for example, Minsky (1978), Moore (1979/83), Bourva (1992), and Werner (2005).

Past and contemporary DSGE models were and still are largely based on the intermediation view, which implies the risk of underestimating the role of banks, credit, and financial accelerator effects. A sizeable set of DSGE model papers could be cited under the financial intermediation view in Figure $1^{8}$. Any paper that refers to banks as being "intermediaries" usually tends to thereby show its affiliation with the intermediation view. An assessment of the consequences of falsely assuming an intermediation view in DSGE models is presented in Jakab and Kumhof (2015).

How cross-border monetary flows are understood in relation to domestic (versus global) money supply is a matter of scope. Monetary flows into a country, for example, in the form of foreign currency deposits (liability) along with reserves (assets) to domestic banks, add to the money stock, that is, mean money creation, as long as one assumes a local economy perspective. From a global perspective, it depends on whether the money inflows are generated

\footnotetext{
${ }^{7}$ It has been observed that part of the origin of the Great Depression in the 1930s may have lain in the FED's "failure to understand the role of money" (Bernanke 2006) at the time. In that context, the origin of defining and empirically measuring monetary aggregates in the US can also be traced back to the 1930s. The first empirical definition of a money stock that came very close to what the US FED still defines as M1 nowadays can be found in Currie (1934).

${ }^{8}$ The fact that they would not fall under the fractional reserve view stems from them being representative agent models with only one bank, if included, and thereby reflecting a pure intermediation view.
} 
via foreign bank loans (money creation at the global level) or the channeling of existing funds (no money creation at the global level). Ponomarenko (2017) focuses on this one form of leakage, the "foreign sector," and discusses the importance of banks' net foreign asset-liability stock position and related flows for influencing deposit stock dynamics, in particular in emerging market economies.

We conclude our literature review with two observations. First, we observe that the money creation understanding is to an extent cyclical, in the sense of it reappearing and becoming more widely understood after "heavy recessions" such as the Great Depression in the 1930s and the GFC in 2007-09. "Normal" recessions of intermediate levels of severity do not seem to have sufficed to let the understanding resurface, as only deep recessions imply drastic needs for rethinking and possibly significant policy action. Second, the money creation literature has, in our reading, not sufficiently emphasized how the "need for liquid funding" squares with the money creation view. This is a gap we aim to fill with this paper.

\section{Definitions}

Nine definitions related to money and credit form the basis for the subsequent work in this paper. They are presented in Box 1 . The first five are well known. The sixth and seventh pertain to our differentiation of bank and nonbank lending, including a distinction between centralized financial institution-based nonbank intermediation versus de-centralized bond market intermediation, and a link to the notion of shadow banking. The eighth definition stipulates the different components of the total money stock to which we refer in the examples that we present later. The ninth definition is central to our discussion, relating to the notion of liquid funding.

The notion of "at par" appears in some of the definitions. By "at par" we mean the initial nominal value that a money holder deposited on a bank's deposit account, that is, without it being at risk of fluctuations in that nominal value. This in turn means that no secondary market has to be approached for redeeming such at par holdings before transferring them, whether into physical cash or in electronic form to other banks.

The distinction between bank and nonbank lending is important from a system perspective. Both bank lending (Definition 6) and nonbank lending (Definition 7) create leverage for the borrower in the same way, while bank lending does, and nonbank lending does not, however, increase system-wide money stocks upon the creation of debt through these two channels (and likewise decrease and do not decrease through repayment in the two categories).

We can equate our notion of nonbank lending (Definition 7) with shadow banking. The Financial Stability Board (FSB), for instance, defines shadow banking as a "system of credit intermediation that involves entities and activities fully or partially outside the regular banking system" (FSB 2014, page 4). We will come back to some details of this definition and what components it effectively comprises in Section IV. We define "nonbank agents" (which appear in some of the definitions below) as including households; nonfinancial firms; nonbank financial firms such as pension funds, insurance companies, investment funds, etc.; as well as state governments (both central and local). Nonbank financial institutions, furthermore, include firm types such as money market funds (MMFs), investment funds, hedge funds, captive financial institutions and money lenders, broker-dealers, structured finance vehicles, trust 
companies, and real estate investment trusts (REITs). They all have in common that they temporarily channel existing money stocks from one subset of economic agents to others ${ }^{9}$.

The notion of "disintermediation" is misleading. Given that bank lending does not mean intermediation (but money creation), while non-bank financial firms' lending implies pure intermediation, the terminology "disintermediation" the way it is used is misled. It conceives bank lending as an intermediation process and the move toward non-bank (shadow bank) lending as a move away from this intermediation.

\section{Box 1. Definitions}

Definition 1: Money. Following standard textbooks (Mankiw 2010), we define money as any medium that is commonly considered to have the following three properties by a sufficient portion of the population ${ }^{10}$ : (1) store of value, for money to allow its holder to conserve purchasing power over time; (2) unit of account, for money to serve as a reference in which the value of goods and services is measured; and (3) medium of exchange, as money is meant to flow for the purpose of settling transactions. This is a social definition that hinges on agents' acceptance of a given medium as money.

Definition 2: Legal money. Legal money is a medium that is prescribed to be money by laws and regulations, that is, imposed by a government. The most tangible criterion of legal money is whether a medium can be used to pay taxes. It may not bear any own intrinsic value, say, when existing in paper or electronic form. The term "legal money" may be used synonymously with "fiat money" and "legal tender."

Definition 3: Commercial bank money. We define commercial bank money as the portion of the total money stock that nonbank agents hold in the form of electronic bank deposits. Nonbank agents can "swap" commercial bank money into physical cash back and forth (equivalently transfer funds electronically across banks), while thereby leaving system-wide money stocks unchanged.

Definition 4: Bank. A bank is a firm whose liabilities consist at least in part of legal money (Definition 2) for other economic agents, who conceive these holdings to be redeemable at par value at all times, to serve the functions of money as outlined under Definition 1.

Definition 5: Nonbank financial firms. They collect and channel on the existing money stocks of other economic agents who serve as "fund providers." Such fund providers' invested amounts of money may not be retrievable at par, that is, be subject to market risk and involve approaching a secondary market to redeem the investment, and hence do not serve the functions of money (Definition 1) while being invested.

\footnotetext{
${ }^{9}$ See FSB (2017/19) for the FSB's system-wide nonbank financial intermediation monitoring framework, which is meant to inform policy and strengthen oversight and regulation; concerning banks' interaction with shadow banks, reducing the susceptibility of MMFs to runs, and aligning banks' incentives in terms of securitization of their loan portfolios. Since 2019, the FSB has moved away from using the "shadow bank" terminology, from now on, referring to them as " nonbank financial intermediation" instead (FSB 2019).

${ }^{10}$ By "sufficient portion" we mean a portion of the population that is high enough for the medium to be socially accepted, which is a precondition for the three functions as outlined under Definition 1 to apply to the medium in reality.
} 


\section{Box 1. Definitions (concluded)}

Definition 6: Bank lending. Bank lending occurs when banks (Definition 4) create a deposit (money) through granting a loan. Bank lending increases total money stocks, while bank loan repayments destroy total money stocks accordingly.

Definition 7: Nonbank lending (= shadow bank lending). Nonbank lending occurs when an economic agent passes existing legal money stocks on to another agent-subtracting from its own money holding and adding to another's - through a debt contract that stipulates its repayment in the future.

Definition 7a: Nonbank lending through centralized nonbank financial institutions. Denotes the nonbank lending process (Definition 7) carried out by nonbank financial firms (Definition 5).

Definition 7b: Nonbank lending through decentralized primary bond markets. Denotes the nonbank lending process (Definition 7) through decentralized primary bond market issuances of debt. They entail the collection of multiple lenders' existing funds to channel them to one borrower.

Definition 8: Components of the total money stock. Total money is the combined value of all units falling under Definition 1. It consists of the following quantities: (1) Commercial bank money (Definition 3); in our examples: deposits. (2) Central bank money: central bank liabilities that are socially accepted money and that are not held as an asset by a bank; in our examples: cash not held by banks, government reserves. (3) Nonbank money: all forms of socially accepted money that are not included in the quantities listed in (1) or (2). ${ }^{/ 1}$

Definition 9: Liquid funding needs. This notion refers to the need for commercial banks to hold reserves at their central bank accounts for the purpose of cross-bank settlement of customer deposits. From an individual bank perspective, liquid funding needs can be satisfied in three ways: (1) by receiving existing deposits (liability side) along with reserves (asset side) from other banks; (2) by borrowing them through money markets from other banks; or (3) by borrowing them from the central bank. ${ }^{/ 2 / 3}$

1/ Banks' reserves in their central bank accounts shall not be considered part of broad money, because the reserves can be used by commercial banks only for backing cross-bank transfers of flows between nonbank public deposit accounts. For example, banks cannot transact directly with the private sector using such reserve stocks; they cannot be spent for either the purchase of financial or nonfinancial products. It should be kept in mind, however, that in the US, commercial banks may use their central bank reserves to purchase newly issued treasury bonds, which implies a liability swap from the bank reserve account at the FED to the sovereign account at the FED (US Treasury 2004).

$2 /$ It is the first option among these three, the pull of existing deposits (along with reserves), that supposedly contributes to the prevalence of the deceived intermediation view.

3/ Our definition of liquid funding needs is compatible with more generic definitions of the kind put forward in the IMF's GFSR (2008), whereby "funding liquidity is the ability of a solvent institution to make agreedupon payments in a timely fashion." Such payments (likely to other banks) require the availability of reserves. 
Examples of nonbank lending through centralized nonbank financial institutions (Definition 7a) include peer-to-peer lending, investment funds, hedge funds, trust companies, etc. Examples of decentralized nonbank lending (Definition 7b) include primary corporate and sovereign bond markets. Secondary bond markets then give bond holders (investors) the opportunity to exchange ownership of existing bond contracts and the associated right for receiving their principal and interest payment flows in the future.

\section{Balance Sheet Stock ANd Flow Mechanics Under BanK AND Nonbank LENDING ${ }^{11}$}

\section{A. Initialization}

We begin with a "tabula rasa" economy, that is, all agents start with empty balance sheets. To show how money can be introduced into an economy without money, we first assume that the private sector agent and the bank agent each gains possession of some real assets, for example, gold (for the sake of our example, it does not matter whether these assets have the quality of non-fiat money or not). So far, there is no fiat money in the system.

Both agents then transfer their assets to a central bank agent in exchange for newly created currency. These initial currency endowments of the agents correspond to the outside (fiat) money in the system, since all other assets (including all non-fiat money) were transferred to the central bank. The assumption of an initial asset transfer ensures that the central bank starts with zero equity.

In principle, a central bank could also distribute currency without receiving any assets in exchange, in which case it would start with negative equity. This negative equity would equal the amount of currency, unless it gained possession of assets in a different manner, for example, through endowment by a sovereign. The one bank agent can be seen as the consolidated banking system. Figure 2 shows the booking statements (flows) along with the resulting balance sheet positions (stocks) after initialization.

\section{B. Granting and Repayment of Loans to the Private Sector}

The creation of loans implies the creation of deposits. These may not initially be backed by central bank reserve amounts of the bank that grants the loan, and in that sense may not be "liquid" in case the newly created deposit would want to be transferred across banks in an electronic manner (or converted into cash, an option we abstract from without loss of generality of our exposition). Figure 3 shows the booking statements and resulting balance sheet structure.

The bank has three options for obtaining reserves to accomplish a cross-bank transfer of the newly created deposit. First, it may borrow reserves from other banks through the interbank market. Second, it may incentivize depositors of other banks to move their deposits to itself, which would flow along with reserves. Third, it may borrow reserves from the central bank.

\footnotetext{
${ }^{11}$ We provide an online companion to this paper, available at http:/www.siebenbrunner.com/moneycreation/, where extended versions of the examples discussed in this section can be found.
} 
Figure 2. Initializing the Balance Sheets

Both the private sector and the bank agent are endowed with physical cash-that is, central bank money. Note that the cash held by the bank agent is not included in the total money stock, hence total money at the end of this example consists of 100 units of central bank money. In the online companion, we present the booking statements occurring when the private sector agent deposits its cash with the bank, and when the bank converts its cash into central bank reserves.

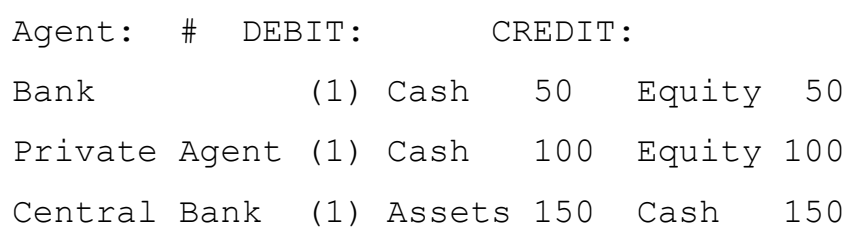

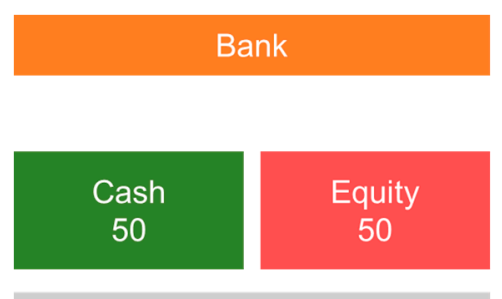

Total Assets: 50
Private Sector Agent

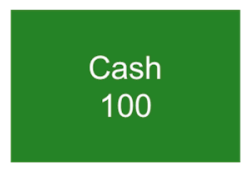

Total Assets: 100

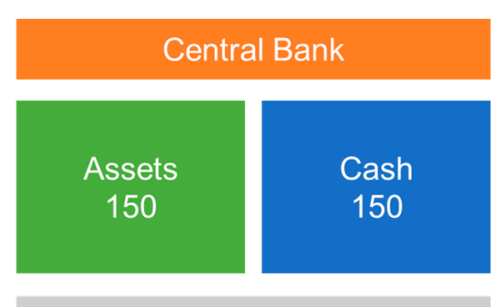

Total Assets: 150

Notes: The first panel shows the booking statements (flows) using standard double-entry bookkeeping conventions and the following syntax:

\section{[Agent] ([i]) [D-Account] [Amount] [C-Account] [Amount]}

Where [Agent] denotes the agent making the booking statement, [i] represents a counting variable used to record all transactions booked by the agent along our series of example transactions. [D-Account] and [C-Account] are the accounts debited and credited by [Amount], respectively.

The second panel shows the resulting balance sheets after all booking statements have been made, where the size of the shapes is proportional to the logarithm of total assets.

Various interest payment flows are involved, which we do not present in detail here ${ }^{12}$. Loan interest rates imply interest income for the banks, which can in turn be assumed to be distributed back to private sector agents through dividends, which are an expense along with deposit interest. Net interest income flows with the private sector add to residual equity of banks; they leave the size of the banking system's consolidated balance sheet unchanged. Interest expense flows for central bank borrowing let the consolidated reserve stock shrink (all else equal), while remuneration on reserves increases reserve stocks ${ }^{13}$.

\footnotetext{
12 Examples related to such additional considerations are presented in the online companion.

13 Since commercial bank reserves at their central bank accounts are usually not included in broad monetary aggregates, such central bank interest payment flows do not affect such aggregates by definition.
} 
Figure 3. Loan Creation for the Private Sector

The first booking statements correspond to a simple initialization with 50 units of bank money. Money creation happens in the second statements, which grow the total money stock to 150, still entirely in the form of commercial bank money. In the online companion we further demonstrate how the repayment of the loan decreases the money stock again, as well as the redistributive effects of interest and bank dividend payments.

\begin{tabular}{|c|c|c|c|c|c|}
\hline Agent: & $\#$ & DEBIT: & & CREDIT: & \\
\hline \multirow[t]{2}{*}{ Bank } & $(1)$ & Reserves & 100 & Equity & 50 \\
\hline & & & & Deposits & 50 \\
\hline Private Agent & (1) & Deposits & 50 & Equity & 50 \\
\hline Central Bank & (1) & Assets & 100 & Reserves & 100 \\
\hline
\end{tabular}

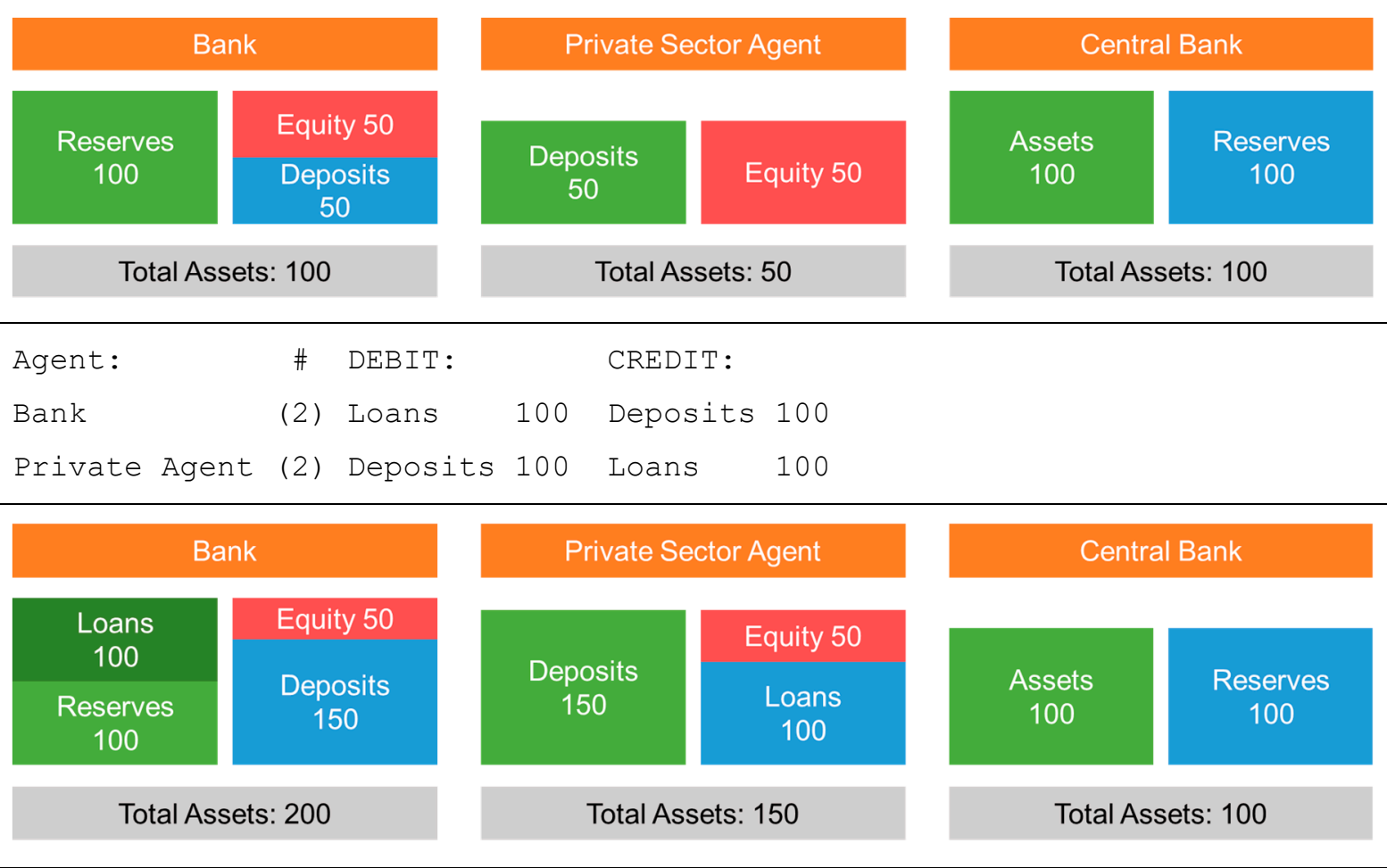

\section{Bank versus Nonbank Lending (Example Involving a Sovereign Borrower)}

Lending by nonbank financial institutions does not change total money stocks (Figure 4). It implies a temporary reallocation of existing monetary funds from one agent to another. In the example, the household sector invests part of its existing money holdings (deposits) in sovereign bonds. The total money stock remains constant throughout the example and would be no different conceptually if we had set it up as a nonfinancial corporate firm's bond issuance instead of a sovereign one. 
Figure 4. Nonbank Lending (Primary Sovereign Bond Market Auction)

The private sector agent and the bank both start with simple, non-empty balance sheets. The government starts with an empty balance sheet. In the second step, the government issues 100 units worth of bonds, which are purchased directly by the private sector agent, using its bank deposits as payment. The total money stock consists of 200 units of commercial bank money throughout the entire example. The booking statements by the central bank are analogous to the previous examples and omitted here for brevity.

$\begin{array}{lcll}\text { Agent: } & \# \text { DEBIT: } & \text { CREDIT: } \\ \text { Bank } & \text { (1) } & \text { Reserves 200 } & \text { Deposits } 200 \\ \text { Private Agent } & \text { (1) } & \text { Deposits 200 } & \text { Equity } 200\end{array}$

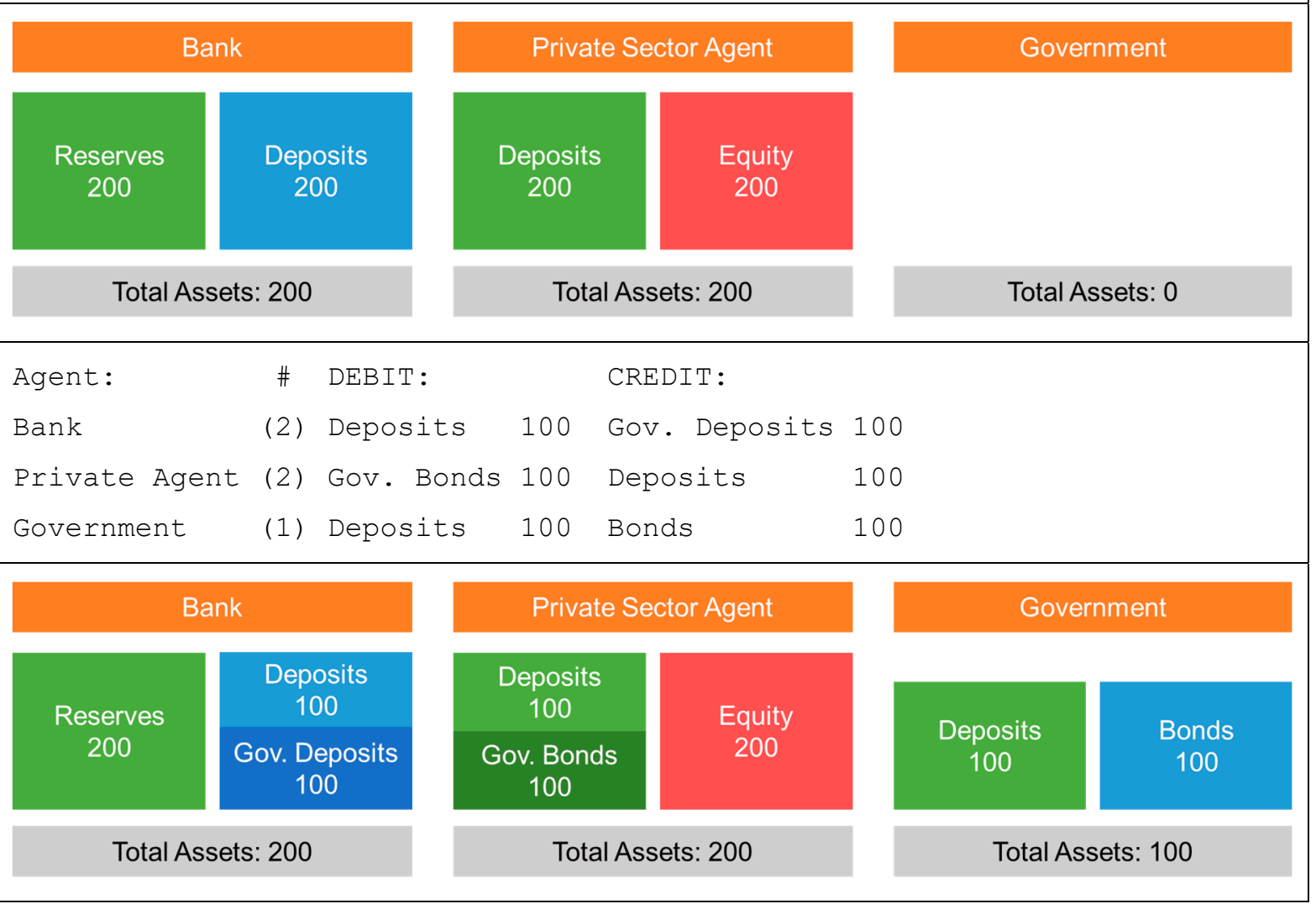

The purchase of bonds issued by banks destroys money temporarily. Bonds issued by banks are excluded from our - and from most typical - definitions of the money stock, rightly so because bank bonds are not necessarily redeemable at par for immediate transaction purposes (see Paragraph 7 and Definition 1). Hence, if bonds are purchased by private sector agents with deposits, this transaction has the effect of reducing the total money stock temporarily. Their repayment means a subsequent feed of that money back to the system. Interest paid on top of the bond principal would increase the money stock to levels exceeding the nominal money stock before the bank bond issuance.

The question arises as to whether the choice between bank loan and bond finance would make a difference for macroeconomic dynamics at large. It appears that not much academic research has been conducted on this question so far. 
When private sector agents' money holdings are invested in sovereign bonds, they cannot be spent otherwise. In that sense, they subtract from the purchasing power of private sector agents, who chose to do so with their savings stocks, which, however, they do not plan to spend momentarily anyhow. From that perspective alone, system dynamics may not differ much when comparing the loan versus bond finance for the sovereign case.

Banks granting loans to the sovereign implies a stronger sovereign bank nexus. The banking system's solvency risk would be more tightly connected to variation in sovereign risk. This additional tie would come on top of explicit and implicit guarantees that the sovereign may carry with regard to the banks' liabilities to the private sector.

\section{Securitization}

The purchase of loans through securitization implies the destruction of money stocks (Figure 5). The purchase price is paid in the form of bank money, which is destroyed in the process of the purchase. The destruction of money through securitization is preceded by the creation of money through loans (see subsection B above), which are about to be securitized. Hence, the eventual outcome of the securitization (here assumed to occur to 100 percent) would render the provision of bank credit equivalent to the nonbank financial intermediation case (see subsection $\mathrm{C}$ above) - that is, the initially newly created money will be neutralized by an investment based on existing money stocks, invested by nonbank financial or nonfinancial agents $^{14}$.

Figure 5. Securitization

In this example, we distinguish between two types of private sector agents: a household, which starts the example with only a loan and corresponding money holdings of 100 , and an investment fund, which starts the example with 100 units of money holdings. The total money stock at the start of the example thus consists of 200 units of commercial bank money. The bank then converts the loan into asset-backed securities (ABS), leaving money stocks unchanged. The fund then uses its money holdings to purchase the ABS at face value, a transaction that reduces total money stocks to 100 units of commercial bank money. The bank removes the corresponding asset from its balance sheet, thus treating the transaction as a "true sale" arrangement.

\begin{tabular}{|c|c|c|c|c|c|}
\hline Agent: & $\#$ & DEBIT: & & CREDIT: & \\
\hline \multirow[t]{2}{*}{ Bank } & (1) & Reserves & 100 & Wholesale Deposits & 100 \\
\hline & & Loans & 100 & Retail Deposits & 100 \\
\hline Fund & (1) & Deposits & 100 & Equity & 100 \\
\hline Household & (1) & Deposits & 100 & Loans & 100 \\
\hline
\end{tabular}

14 The amount of money destroyed corresponds to the purchase price of the securitized loans, which is not necessarily equal to the value of the loan and hence the money that was initially created when granting the loan. 


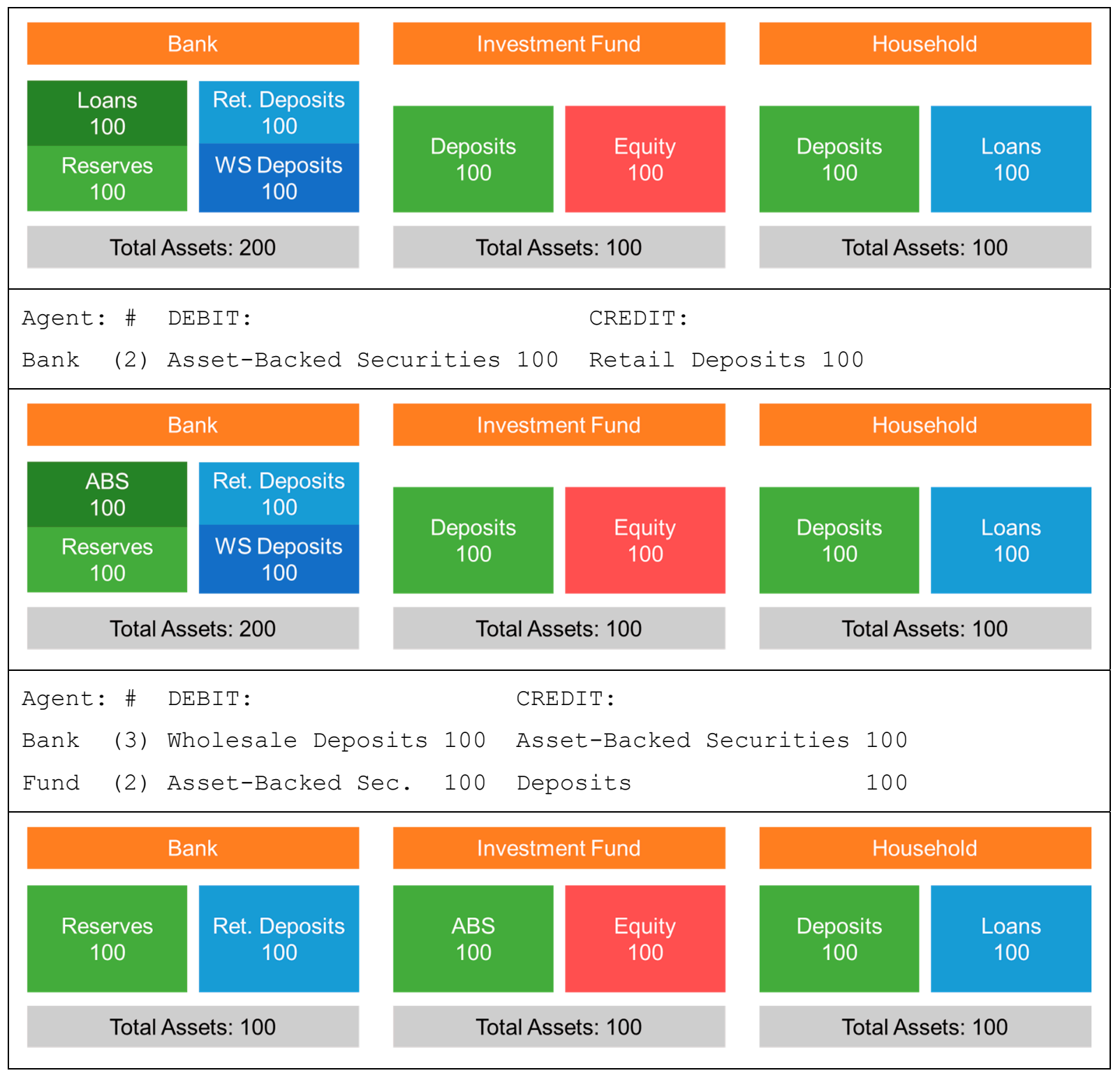

\section{Agent-Based Model Simulation}

We present an $A B M$ to illustrate how banks - even when they are unconstrained by regulation in their ability to create money - can face a situation of liquid funding shortfalls. In the model presented in the following, the central bank is willing to refinance the banks unconditionally. In reality, the central bank may be constrained by its mandate or unwilling to do so, thus making it possible that solvent banks fail due to illiquidity.

Our monetary ABM comprises one central bank along with banks and private sector agents. Our $\mathrm{ABM}$ comprises one central bank $(\mathrm{CB}), \mathrm{b}=1, \ldots, \mathrm{B}$ commercial banks and $n=1, \ldots, \mathrm{N}$ private sector agents. There is no physical cash by assumption, for all money in the hands of the $\mathrm{N}$ private agents being held in electronic form in deposit accounts at the B banks. Private agents can be seen as consumers and firms at the same time. Figure 6 shows a schematic of the components of the ABM, which are described briefly below. A form of annotated pseudo code 
for the ABM is presented in Annex I, along with an outline of how the simulated model outcome behaves as a function of the core model parameters.

The model is very stylized, involving hardly any behavioral elements for the agents in the model. The stylized nature of the model and the absence of behavioral rules mean that the model is not meant to be fitted to real world data. The model's sole purpose lies in making some conceptual points about money creation and liquid funding and transfer processes, to reflect reality in these specific respects.

The three agent sets' individual balance sheets are initialized using a random drawing procedure and integrated for all balance sheets to be cross-consistent and connected. Private sector agents' money stocks are drawn from a uniform distribution. The $\mathrm{N}$ private sector agents are assigned permanently to the B banks. The private agents' money holdings are held in electronic form in their bank deposit accounts.

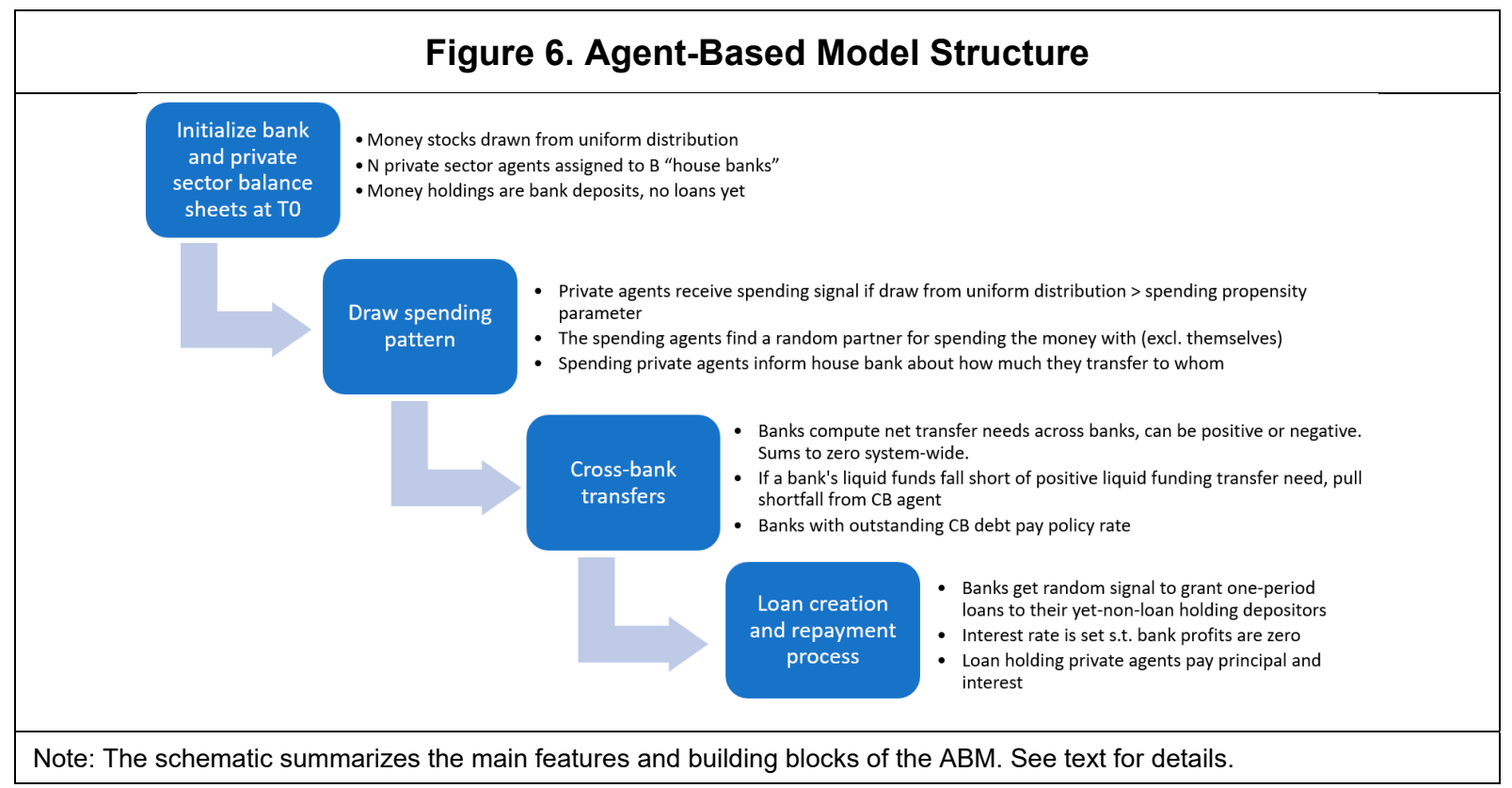

The spending process in the model is random. Each period, all private sector agents receive random signals to spend, in which case they get a randomly chosen other private agent assigned as a recipient. The random spending signal is based on a uniform random draw, which is compared to a threshold parameter, and which we refer to as the "spending propensity." Spending flows are uniform random and set as a percentage of money holdings. The latter parameter we call the "spending fraction."

A cross-bank net settlement process follows. Banks compute their net deposit transfer needs, which can be positive or negative in a given period, and which sum to zero at the system level at all times (net financial flows sum to zero just as net financial asset stocks do, since each one agent's financial asset must be another one's liability). If a bank's liquid funding needs exceed their available reserve amount at the CB agent's account, they borrow the required residual reserve amount from the $\mathrm{CB}$. In the model, the bank agents do not have the option to borrow reserves from other banks or to actively incentivize private sector agents from other banks to move deposits, along with reserves, into a bank. 
A random loan creation and subsequent repayment process follows. There are random loan granting signals for the banks to create uncollateralized credit for the private sector agents at an endogenous loan interest rate $i$. The random signal is again based on a uniform random draw and a threshold model parameter on the $[0,1]$ interval, which is referred to as the "loan granting propensity."

On the liability side of the banks, deposits imply a zero expense by assumption. The only expense flows that banks face in the model is for CB reserve borrowing, with $r$ denoting the $\mathrm{CB}$ funding rate. We will later see that the relation between the loan interest rate $i$ and the CB rate $r$ depends on how many banks there are and how frequent intrabank transfers are. The policy rate follows a white noise random Normal process ${ }^{15}$.

The model abstracts from numerous other economic realities. First, none of the agents can default. Second, there is no money market. Should non-zero net transfers need to be backed by liquid funds that are temporarily unavailable at the bank, the CB's standing borrowing facility will have to be called. Third, there is no explicit distinction between consumption and investment flows. The term "spending" is meant to be the neutral expression comprising both household consumption and firm investment flows. Fourth, profit margins are set to zero in the model, although they would be positive and a function of competition in the system (the number of banks) in reality. All these features are on purpose excluded from the scope of the model for its structure to be reduced to the essentials that are needed to make our points. Importantly, the addition of any of such "relevant realities" would not change the conclusions that we draw from the model.

A baseline simulation was run with $B=30$ banks, $N=500$ private agents, and $T=600$ periods. The threshold spending propensity parameter was set to 25 percent, the spending fraction to 50 percent, and the loan granting probability to 75 percent. The system aggregates for various stocks and flows for the aggregate private and banking sectors are depicted in Figures 7 and 8.

Figure 9 shows how a reduced subset of model variables behaves as a function of the number of banks. The CB funding over bank equity ratio, the percentage of banks pulling CB reserves, and the loan interest rate all fall monotonically with a decreasing number of banks, while the policy rate remains at a mean of 2 percent with some stochastic fluctuation (not shown in Figure 9). The size of the aggregate banking system and private sector balance sheets remain unaffected, just as all spending frequencies, spending flows, loan flows, loan stocks, etc. The correlation between the policy rate and the loan interest rate falls to zero. Hence the only effect that the variation of the number of banks has is that the same amount of monetary flows through the system need to be settled in an increasingly fine-grained banking system in which a rising share of transfers must be backed by liquid funds that are not initially available in the system and have therefore to be pulled from the CB. Importantly, we do not argue that the effective loan interest rate would fall toward zero in reality if the number of banks was compressed toward zero; the effect of falling competition, and hence more sizeable profit margins, may dominate and do the opposite to effective loan rates. The conclusion in terms of the vanishing correlation of policy rates with loan interest rates, however, would keep holding up, which is the main point we aim to make.

\footnotetext{
${ }^{15}$ With a mean of 2 percent and standard deviation of 1 p.p. This setting is entirely ad hoc. Changing this mean and variance does not change the basic conclusions we draw from the model.
} 
Figure 7. Exemplary Simulation Path for Selected Model Variables (Stock Variables)

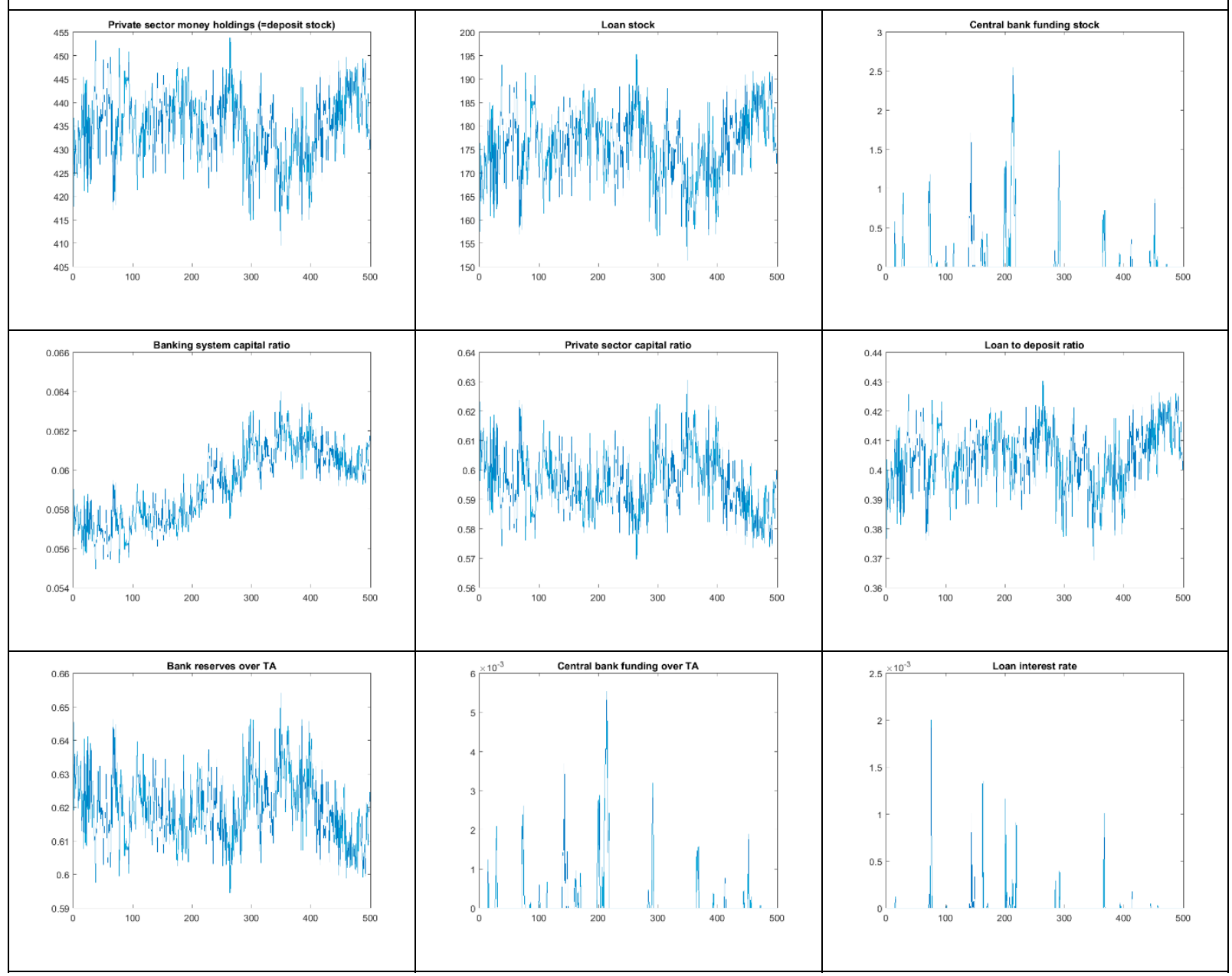



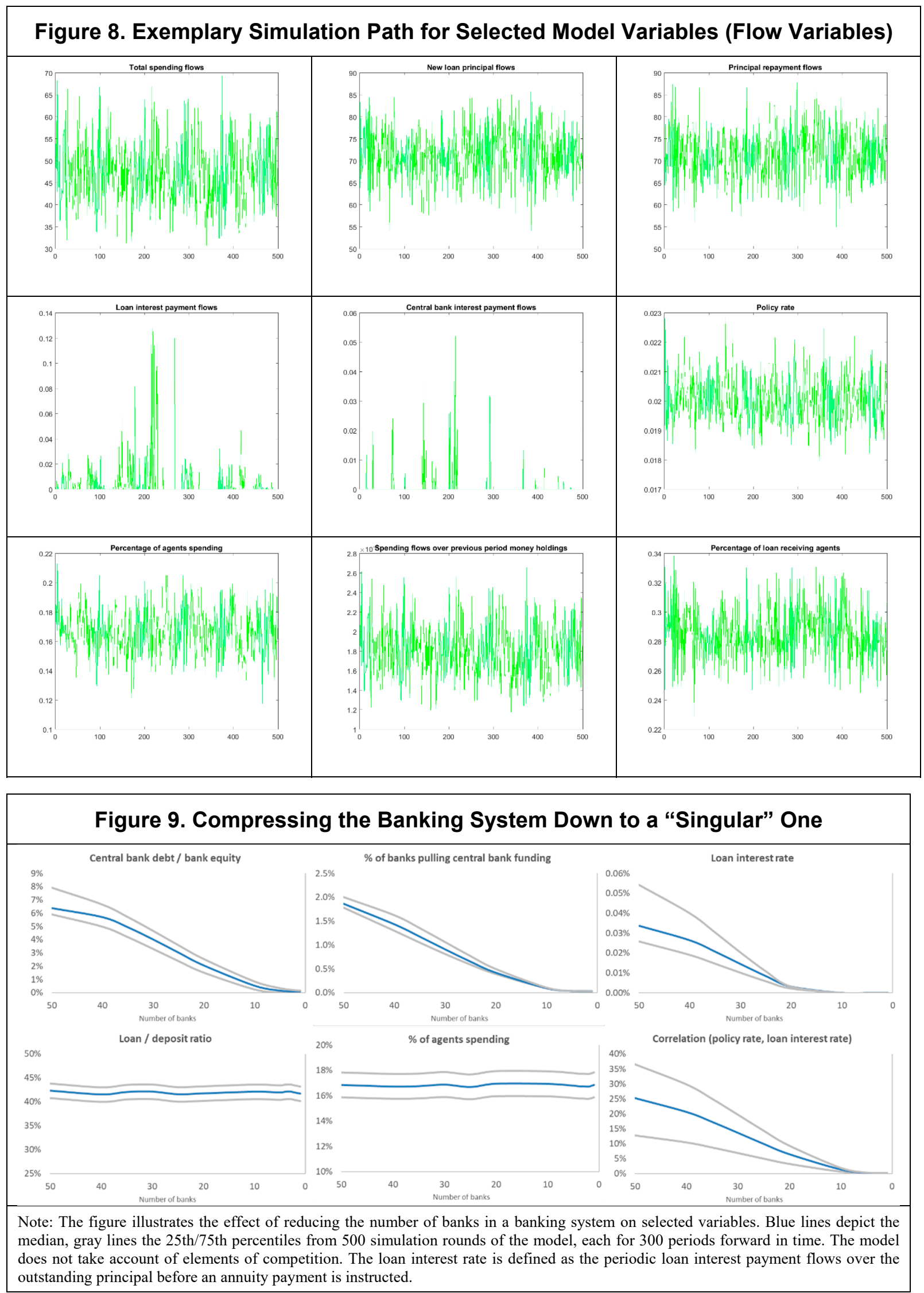


\title{
VI. Central Bank Digital Currency (CBDC)
}

\begin{abstract}
Numerous monetary authorities around the world consider introducing (experiment with) retail CBDCs: their introduction would mean that private sector agents' money holdings could be held as an electronic central bank liability. Commercial banks have held their reserves in electronic form at their central bank accounts for decades, which is conform with the CBDC definition and just being confined to banks. Useful entry points to the recent discussions around retail CBDC design, its underlying rationale, costs, benefits, etc., can be found in Mancino-Griffoli et al. (2018), Bindseil (2019), and Barontini and Holden (2019) ${ }^{16}$.
\end{abstract}

An unregulated introduction of CBDC creates the risk of a cliff-effect threatening to undermine financial stability. It is conceivable that the benefits of CBDC will not immediately be internalized by private sector agents. In a healthy economy, old conventions with regard to the treatment of bank deposits as money may continue to hold, in particular when commercial bank deposit interest rates would be set at a margin above a CBDC rate (whether itself zero or positive). This may change abruptly at the onset of a crisis, however. If the viability of private banks would be called into question, agents may disregard the higher interest on bank deposits and collectively flee into CBDC. This would effectively constitute an "electronic" bank run, with all the known consequences for banks' liquidity (reserve shortage/insufficiency). Given the relative inconvenience of physical cash compared to bank deposits, the promise of deposit insurance is an adequate tool for mitigating this risk in the current monetary system. This may, however, no longer be the case in a system where a convenient alternative to deposit money is available.

Regulations regarding the use of $\mathrm{CBDC}$ can address some of the financial stability risks posed by its introduction. While a CBDC would conceivably always be treated as legal tender, the sovereign still can restrict its use as social money, per Definition 1. By imposing limits on how much CBDC can be held by any one individual (stock constraints), the sovereign could effectively curtail its use as a store of value. Further imposing limits on transaction volumes (flow constraints) can be used to reduce its use as a medium of payment, restricting its use to smaller transactions and thereby rendering it more similar in usability to physical cash.

Conventional central bank policy tools can further mitigate the risks from introducing CBDCs. The interest rate on CBDC deposits can be an effective tool for managing the desirability of CBDC holdings relative to bank deposits, and even negative interest rates on such deposits could easily be implemented. Small differences in interest rates are unlikely to prevent a bank run, however. In the case of a bank run, the central bank in principle has unlimited resources to refinance banks. In practice, however, it may be constrained by its mandate to do so: if banks with solvency problems are hit by bank runs, then these may in fact

\footnotetext{
${ }^{16}$ Selected additional entry points to the related evolving literature include the following (see also references therein): Davoodalhosseini (2018) discusses the welfare implications that the existence of CBDCs next to deposits and cash may have. Estimates based on his calibrated model suggest a permanent gain in terms of consumption at 0.6 percent for Canada and 1.6 percent for the United States. Engert and Fung (2017) argue, among other points, that reducing the effective zero lower bound does not provide a compelling reason for issuing CBDC; as well as that "helicopter money" considerations may not work as theorized if a CBDC is meant to be anonymous and when foreigners may hold it as well. Barrdear and Kumhof (2016) and Fernandez-Villaverde and Sanches (2016) appear to be among the few papers that present larger scale structural models to explore the impact of CBDCs.
} 
not have sufficient assets of high enough quality to be used as collateral in emergency liquidity assistance programs.

As with deposit money, a crucial question is how the lending process under a CBDC system would work. To the best of our knowledge, this question is not yet explicitly addressed in the ongoing discussions around CBDC. In principle, the introduction of a CBDC could occur entirely through open market transactions, for example, the purchase of government bonds on secondary markets, or even through more radical options amounting to "helicopter money" distributions. In an economy that fully transitions to central bank money, it seems unlikely, however, that such actions could sustain sufficiently high money creation flows to avoid deflationary tendencies. We are thus interested in how lending that is denoted directly in CBDC could occur, and what role commercial banks would play in such a system. Figure 10 presents two possible implementations of such a system ${ }^{17}$.

Figure 10. CBDC-Denoted Lending

\section{0a: Bank-Originated Lending Denoted in CBDC}

One option for banks is to directly grant loans denoted in CBDC. The banks would first have to obtain CBDC from the central bank, which they could then pass on to private sector agents in exchange for a loan. Lending in such a system would resemble a loanable funds process, or a 100 percent reserve system, respectively. It still implies money creation at the system level if banks' own CBDC holdings are not counted as money. A definition of a monetary aggregate might want to be reconsidered in this case, however, since the CBDC holding of the bank could be used directly as a means of payments by the bank (unlike its reserve holdings at a central bank currently).

\begin{tabular}{llllll} 
Agent: & $\#$ & DEBIT: & \multicolumn{3}{l}{ CREDIT: } \\
Bank & (1) & CBDC & 100 & Equity & 100 \\
Central Bank & (1) Assets & 100 & CBDC & 100 \\
Bank & (2) & Loans & 50 & CBDC & 50 \\
Private Agent & $(1)$ & CBDC & 50 & Loans & 50 \\
\hline
\end{tabular}

\begin{tabular}{|c|c|c|c|c|c|}
\hline \multicolumn{2}{|c|}{ Bank } & \multicolumn{2}{|c|}{ Private Sector Agent } & \multicolumn{2}{|c|}{ Central Bank } \\
\hline $\begin{array}{c}\text { CBDC } \\
50 \\
\text { Loans } \\
50\end{array}$ & $\begin{array}{l}\text { Equity } \\
100\end{array}$ & $\begin{array}{c}\text { CBDC } \\
50\end{array}$ & Loans 50 & $\begin{array}{c}\text { Assets } \\
100\end{array}$ & $\begin{array}{c}\text { CBDC } \\
100\end{array}$ \\
\hline \multicolumn{2}{|c|}{ Total Assets: 100} & \multicolumn{2}{|c|}{ Total Assets: 50} & \multicolumn{2}{|c|}{ Total Assets: 100} \\
\hline
\end{tabular}

\section{0b: Loans Originated on the Central Bank Balance Sheet}

An alternative approach to lending denoted in CBDC would be for the central bank to grant such loans directly to private sector agents. Commercial banks could still play a role in such a system, for example, by subsequently purchasing the loans from the central

\footnotetext{
${ }^{17}$ Further details are presented in the online companion.
} 
bank. If the commercial bank commits to this purchase before the loan is granted, it would
allow the central bank to effectively shift the burden of screening and monitoring debtors
to the commercial bank. This would include the initial loan granting and contract design
process, which a central bank can likely not manage itself. Commercial banks would in
that sense act as an "operating arm" of the central bank. The example booking statements
below, where the commercial bank uses CBDC instead of reserves to purchase the loan
from the central bank, result in the same final balance sheet composition as the above
sequence. However, in this system, the central bank bears the credit risk until the transfer
to the commercial bank is complete, which implies a specific kind of settlement risk (see
the discussion in the online companion).
$\begin{array}{llll}\text { Agent: } & \text { (1) CBDC } 100 \text { Equity } 100 \\ \text { Bank } & \text { (1) Assets } 100 \text { CBDC } 100 \\ \text { Central Bank } & \text { (2) Loans } 50 \text { CBDC } 50 \\ \text { Central Bank } & \text { (1) CDBC } 50 \text { Loans } 50 \\ \text { Private Agent } & \text { (3) CBDC } 50 \text { Loans } 50 \\ \text { Central Bank } & \text { (2) Loans } 50 \text { CBDC } 50 \\ \text { Bank } & \end{array}$

If the risks of transitioning to a CBDC are well managed, it constitutes a viable option to switch the economy to a "full money" system. As noted in the discussion on the Chicago plan (Section II), removing private banks' money creation ability may offer potential benefits (a more detailed discussion of related pro and contra arguments is beyond the scope of this paper). We merely caution here that the transition, if not well managed, could induce serious unintended consequences. If well managed, however, a CBDC may be a useful tool for ensuring a smooth and gradual transition towards a full money system.

The move to a 100 percent CBDC reserve system can come into existence in three ways. First, if imposed by a central bank when requiring loans granted in commercial bank deposit form to be backed 100 percent by central bank reserves (CBDC); second, by granting loans in CBDC on the central bank balance sheet right away; or third, when private sector agents would choose to shift virtually all their commercial bank deposits (created through commercial bank loans and deposits) to their CBDC accounts. In the first two cases, the move to the "full money" system would be imposed, while the third scenario could come about without even being intended by a regulator.

\section{Conclusions}

We have highlighted that money creation and liquid funding needs are two realities that coexist. Liquid funding needs in the form of commercial banks' reserves in their central bank accounts are relevant to back payment transfers in a multi-bank system, which is a point that some readers may argue is trivial. Liquid funding needs, whether addressed ex ante or ex post relative to the loan creation process, and whether based on pulling deposits along with reserves from other banks, through interbank markets, or standing borrowing facilities from a central bank, do not negate the fact that banks create deposits and hence money "out of nothing" upon the creation of loans. 
We have considered a hypothetical thought experiment, assuming that a commercial banking system was reduced to a singular system, in which case the central bank would lose its handle on economic dynamics. In the presence of only one bank (and the absence of physical cash), liquid funding needs would cease to exist and the central banks' handle via conventional policy instruments over bank funding costs, hence bank loan interest rates and in turn macroeconomic conditions, be lost $^{18}$. We have illustrated that fact based on a simple, stock-flow consistent monetary ABM.

From our discussion related to CBDCs, we conclude that the mere disappearance of physical cash would not imply that monetary policy's bearing on economic dynamics be in any way reduced. The disappearance of cash cannot be the argument for calling for CBDCs from that perspective. More relevant arguments for digital instead of physical cash include instead the objective to be better able to counteract money laundering and combat the financing of terrorism and tax evasion.

An important question that should be explored in detail concerns how a loan-granting process would be designed in a system with a CBDC parallel to commercial bank money. A 100 percent backing of loans by digital CBDC, if implemented as such, would indeed imply an implementation of the Chicago plan as considered in the 1930s in the aftermath of the Great Depression. The shift to such a full money system could also come about without regulations, if private sector agents decide to prefer CBDC to bank deposits as social money. It would in any case mark a highly significant change to the financial system structure.

Pure financial intermediary business, which is flourishing as part of FinTech developments in many countries (e.g. in the form of peer-to-peer lending), may not be able to fully replace bank lending. This is a one of two conclusions that are tangent to our main conclusions above. Pure intermediaries' lending potential is bound by standing money stocks in the system that are not required for transaction purposes (that is, saved), while banks' lending implies money creation, and hence is more elastic and bound only by regulatory requirements and demand.

The merits of financing government expenditures based on bank loans as opposed to bonds should warrant deeper conceptual and quantitative research. This second tangent conclusion concerns the differential effects that the two forms of government finance may entail and relate to possible crowding-out effects that bond finance (intermediation) might imply, which bank loan-based financing (money creation) would not. On the other hand, the stronger sovereign-bank nexus that bank lending to the government would entail may be seen as a concern.

\footnotetext{
${ }^{18}$ Central banks may still be able to influence macro-financial dynamics through the conduct of macroprudential policies. The thought experiment here concerns only conventional interest-rate-based monetary policy instruments.
} 


\section{Appendix I. ABM-Pseudo Code}

Step A: Initialization of balance sheets at $\mathrm{t}=0$

[A.1] Money stocks $M_{t=0}^{n}$ are drawn from a uniform distribution and assigned to all $N$ private agents. Private agents possess nothing but these money holdings in period $t=0$. Thus, their money stock equals their residual net worth and their balance sheets are balanced in that trivial sense.

[A.2] The $N$ private agents are assigned in equal shares to the $B$ banks. They are called their "house banks," as they remain assigned to them during the simulation throughout Steps B-D below.

[A.3] The deposit stocks for the banks, denoted $D_{t=0}^{b}$, are set to the sum of their depositors' money stocks, and in turn set equal to the banks' liquid reserve stock $R_{t=0}^{b}$ on their asset side. Assuming that banks have zero own funds, their balance sheets balance as $R_{t=0}^{b}=D_{t=0}^{b}$. At $t=0, \sum_{b=1}^{B} R_{t=0}^{b}=\sum_{b=1}^{B} D_{t=0}^{b}=\sum_{n=1}^{N} M_{t=0}^{n}$. There are no outstanding loan stocks $L$, yet.

Steps B, C, and D now describe the recursive simulation of the economy for $t=1, \ldots, T$ forward in time. The sequence of steps from the beginning of Step B. 1 to the end of Step D.3 constitute one time period.

\section{$\underline{\text { Step B: Draw spending pattern }}$}

[B.1] Private agents receive a signal $s_{t}^{n}$ to spend $\left(s_{t}^{n}=1\right)$ if a uniform random number draw is larger than the spending propensity $P^{s}$. Otherwise the agents do not spend $\left(s_{t}^{n}=0\right)$. Given a positive spending signal, an agent is to spend a uniform random fraction $F^{s}$ of its current money holdings $D_{t-1}^{n}$ (including in that stock an amount it may have received in $t-1$ through a loan).

[B.2] Private agent spending partners are determined randomly for all those agents who got the signal to spend. These partners can be themselves spending or nonspending agents according to the outcome of Step B.1. Agents may receive payment inflows from none, one, or more than one other agent ${ }^{19}$. Spending partner assignments are redrawn every period.

[B.3] Spending private agents inform their house bank about how much to transfer to whom. The recipients' deposit accounts can be at the same or other banks (the latter only if $B>1$ ).

\section{$\underline{\text { Step C: Cross-bank transfers }}$}

[C.1] Banks jointly compute their net transfer needs $T_{t}^{b}$ across banks, which can be positive or negative for each bank. Net transfers sum to zero at the system level, that is, $\sum_{b=1}^{B} T_{t}^{b}=0$. [C.2] Banks compare their own required net transfer flow $T_{t}^{b}$ with their reserve stocks $R_{t-1}^{b}$. Banks for which $T_{t}^{b}>R_{t-1}^{b}$ borrow $\Delta F_{t}^{b}=T_{t}^{b}-R_{t-1}^{b}$ from the CB which are transferred and added at this point to $R_{t-1}^{b}$ on the asset side and the CB funding stock $F_{t-1}^{b}$ on their liability side.

\footnotetext{
${ }^{19}$ Introducing a constraint that would allow an agent to receive inflows from no more than one agent does not change the dynamics of the model in any notable way.
} 
[C.3] Cross-bank transfers $T_{t}^{b}$ are settled for all banks.

[C.4] Banks pay an interest expense related to their outstanding CB balance at a current policy rate $p_{t}$ (set by the CB at the beginning of period $t$ ), subtracting from $R_{t-1}^{b}$ but not from $D_{t-1}^{b}$, reducing the banks' residual equity position (normally zero) momentarily within the period.

[C.5] Banks for which $T_{t}^{b}<R_{t}^{b}$ pay off as much as possible of their outstanding CB loan balance, that is, the minimum of $F_{t}^{b}$ and $R_{t}^{b}$, which then fall in parallel by that same minimum amount.

\section{$\underline{\text { Step D: Loan creation process }}$}

[D.1] Banks get a random signal to grant a one-period loan, using a uniform random draw for the subset of their own yet-non-loan-holding depositors, against a threshold probability $P^{L}$. If a loan is to be granted, then the corresponding principal amount is drawn from a uniform distribution implying the amount $V^{n}$, which is added to the loan stock $L_{t-1}^{b}$ and the deposit stock $D_{t-1}^{b}$, reflecting the creation of money for all private agents that got a new loan contract. The interest rate for the new loan contracts is not yet determined.

[D.2] Banks set the loan interest rate $i_{t}^{b}$ for their loan contracts granted in $t-1$ (in Step D. 1 in the previous iteration) in a way to cover their CB funding expense in $t$, if it was positive, as just implied and transferred in Step C.5, to thereby make their business net equity neutral, and not requiring own funds buffers.

[D.3] Loan holding private agents who received a loan in $t-1$ repay their outstanding principal to their house bank. In addition, they pay interest related to their principal using the house bank-specific loan interest rate $i_{t}^{b}$, just computed in Step D.2. The combined annuity flow is settled. The principal repayment flow subtracts from the loan stock $L_{t-1}^{b}$ and deposit stock $D_{t-1}^{b}$ of the bank (money destruction). The interest payment flow subtracts from the deposit stock $D_{t-1}^{b}$ but not from $R_{t-1}^{b}$ (deposit-bank equity swap).

The fact that the loan rate for loans granted in period $t$ is set in period $t+1$ in Step D.2 resembles a variable loan interest rate regime.

Should private agents not be able to service their annuity (sum of principal and interest flows) in Step D.3 because of insufficient money holdings in period $t$, they pause one period and get assigned a "spending block" for period $t+1$. The spending block is meant to increase the likelihood that the annuity can be paid in $t+1$ when the private agent may have been the recipient of a spending inflow, though it may, by chance, take more than one period, that is, the spending block may be active for more than one period. The interest income flow for the bank in a period in which one or more agents do not service their annuity will be smaller than expected by the bank, making its net equity move from the zero position into slightly negative territory over two or more consecutive periods. When the delinquent borrowers surely repay sooner or later due to the spending block (as surely randomly becoming spending receivers), the bank's temporary negative equity position shall always move back to zero eventually. The temporary delinquencies are not interpreted as defaults here, as the allowance for only delayed repayment implies that banks do not face losses in the form of write-offs of debt, in which case the notion of default would be warranted. There is a zero 
spread between loan interest rates that is set endogenously by the banks and their weighted average cost of funding because there is no credit risk and hence expected losses are zero by design.

Table A shows how the various stock and flow measures would react when changing (increasing) four parameters of the model: the spending propensity (SP), the spending fraction $(\mathrm{SF})$, the loan granting probability (LP), and the number of banks (\#B).

\section{Table A: Model parameter sensitivities}

\begin{tabular}{|c|c|c|c|c|c|}
\hline & & SP & SF & LP & \#B \\
\hline \multirow{11}{*}{ Banks } & Reserve stock [R] & $\Rightarrow$ & $\Rightarrow$ & $\Rightarrow$ & $\Rightarrow$ \\
\hline & Loan stock [L] & $\Rightarrow$ & 个 & $\mathbb{P}$ & $\Rightarrow$ \\
\hline & Deposit stock [D] & $\Rightarrow$ & $\Rightarrow$ & $\Rightarrow$ & $\Rightarrow$ \\
\hline & Central bank funding stock [F] & b & A & A & $\mathbb{P}$ \\
\hline & Residual equity stock [E] & $\Rightarrow$ & a & 个 & $\widehat{A}$ \\
\hline & $R /(L+R)$ & $\Rightarrow$ & $\sqrt{b}$ & $\sqrt{b}$ & $\Rightarrow$ \\
\hline & L/D & 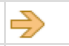 & A & A & 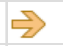 \\
\hline & $E /(L+R)$ & $\Rightarrow$ & 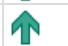 & A & $\widehat{A}$ \\
\hline & $\mathrm{F} / \mathrm{E}$ & $\sqrt{b}$ & $\mathbb{A}$ & 个 & $\widehat{A}$ \\
\hline & $F /(L+R)$ & $\sqrt{ }$ & $\mathbb{A}$ & A & $\mathbb{P}$ \\
\hline & $\%$ of banks pulling $\mathrm{F}$ & $\sqrt{4}$ & A & A & A \\
\hline \multirow{5}{*}{$\begin{array}{l}\text { Private } \\
\text { agents }\end{array}$} & Money holdings [M] & $\Rightarrow$ & $\Rightarrow$ & $\nabla$ & $\Rightarrow$ \\
\hline & $(\mathrm{M}-\mathrm{L}) / \mathrm{M}$ & $\Rightarrow$ & $\sqrt{b}$ & b & $\Rightarrow$ \\
\hline & spending flows & A & $\mathbb{1}$ & $\Rightarrow$ & $\nabla$ \\
\hline & $\%$ of agents spending & $\xi$ & $\sqrt{b}$ & T & 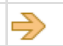 \\
\hline & $\%$ of agents with spending block & $\Rightarrow$ & $\sqrt{4}$ & $\sqrt{4}$ & $\Rightarrow$ \\
\hline \multirow{5}{*}{$\begin{array}{c}\text { Focus: } \\
\text { Loan } \\
\text { business }\end{array}$} & Loan interest rates & $\sqrt{b}$ & A & A & A \\
\hline & $\%$ of agents receiving new loans & $\nabla$ & $\sqrt{b}$ & T & $\Rightarrow$ \\
\hline & New loan flows & $\Rightarrow$ & $\sqrt{b}$ & 个 & 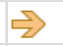 \\
\hline & Principal repayment flows & $\Rightarrow$ & $\sqrt{b}$ & A & $\Rightarrow$ \\
\hline & Interest payment flows & $\sqrt{4}$ & A & A & $\hat{A}$ \\
\hline
\end{tabular}

Increasing the spending propensity implies that spending flows increase, and that less CB funding is required to back the flows in the system, the reason in turn being that intrabank transfers are increasingly likely to be offset through transactions in and out of any one bank. The size of the private sector and banking system balance sheet, including loan and reserve stocks, all remain unaffected. The loan interest rate and corresponding loan interest payment flows decrease as a direct consequence of less CB funding being required.

Elevating the loan-granting probability has the obvious consequence that loan stocks increase, and hence do all related flows such as new loan flows and principal repayment flows. Along with them, the deposit stocks (that is, private sector money holdings) increase, reflecting the link between loans and deposits through the money creation mechanism. Spending flows increase in absolute terms. Since CB funding flows increase, so do the loan interest rates and absolute loan interest payment flows from private agents toward banks increase. 


\section{APPENDIX II. ENDOGENOUS MONEY AND MONEY CREATION-USEFUL QUOTES FROM Past Literature}

The quotes below relate to the topics of endogenous money and money creation, including from economists as well as central bank officials.

Schumpeter 1912: "The function of the banker, the manufacturer of and dealer in credit, is to select from the gamut of plans offered by entrepreneurs... enabling one to implement their plans and denying this to another [...] this alters the analytic situation profoundly and makes it highly inadvisable to construe bank credit on the model of existing funds being withdrawn from previous uses by an entirely imaginary act of saving and then lent out their owners. It is much more realistic to say that the banks 'create credit', that is, that they create deposits in their act of lending, than to say that they lend the deposits that have been entrusted to them. And the reason for insisting on this is that depositors should not be invested with the insignia of a role which they do not play. The theory to which economists clung so tenaciously makes them out to be savers when they neither save nor intend to do so; it attributes to them an influence on the 'supply of credit' which they do not have. The theory of 'credit creation' not only recognizes patent facts without obscuring them by artificial constructions; it also brings out the peculiar mechanism of saving and investment that is characteristic of fully-fledged capitalist society and the true role of banks in capitalist evolution."

Rogers 1929: “... a large proportion of ... [deposits] under certain circumstances may be manufactured out of whole cloth by the banking institutions themselves."

Keynes 1930: “... [a bank] may itself purchase assets, i.e. add to its investments, and pay for them in the first instance at least, by establishing a claim against itself. Or the bank may create a claim against itself in favour of a borrower, in return for his promise of subsequent reimbursement; i.e. it may make loans or advances."

Wicksell 1935: "The lending operations of the bank will consist rather in its entering in its books a fictitious deposit equal to the amount of the loan."

Towers 1939 (Governor, the Bank of Canada 1934-54): "Each and every time a bank makes a loan, new bank credit is created - new deposits - brand new money."

Culbertson 1958: "A change in the volume of demand deposits, in contrast, is initiated by banks when they change the volume of their debt holdings; the banks' creditors, as such, play no active role in the process. The banking system "creates credit" by acquiring debt and creating demand deposits to pay for it. The commercial banks do not need "to borrow loanable funds from spending units with surpluses" in order to extend credit."

Smith 1959: "Commercial bank credit creation makes funds available to finance expenditures in excess of the funds arising out of the current income flow. [...] Commercial banks [...] are distinctly not intermediaries. That is, the decision to save a portion of current income and to hold the savings in the form of a demand deposit does not make any more funds available to the capital market than would have been available had the decision been made to spend instead, and does no more than to restore to the commercial banking system the lending power that was lost when the original cheque was written to transmit income to the recipient."

Minsky 1960: "A commercial bank lends by crediting the borrower with a demand deposit and it invests either by crediting the seller of the security with a demand deposit or by writing a check 
on itself in favor of the seller of the security. The bank expects that the borrower or the seller of the security credited with a deposit will use their deposit very soon after it is created. This will result in checks being drawn on the initiating bank. In a banking system with many banks, [...] the expectation is that the checks drawn on any particular bank will be deposited in another bank. The bank upon which the check is drawn must pay the bank in which the check is deposited the face amount of the check. This payment takes place by transferring reserves or banker's money. In an active trading community offsetting claims for payments arise among the banks. Bankers are sophisticated enough to set up a clearing arrangement so that only the difference between payments from a bank and payments to a bank are made in the form of reserve money. [...] Within a banking system with a stable amount of deposits and distribution of customers, and assuming that no striking changes are taking place in the economy, a particular bank will expect that in the long run the value of the checks written on it and the value of the checks deposited in it will be equal. On the average a bank in such an environment will not have any clearing losses. However, there will be random, seasonal and cyclical shifts of deposits among the banks. In order to be able to meet the clearing losses which result from such shifts, a prudent banker will always try to keep some minimum ratio of reserve money to its deposits and will always try to have its portfolio of earning assets so arranged that it can acquire additional reserve money when needed without paying too great a penalty. From a banker's perspective, the purpose of the reserve is to enable a banker to meet the clearing drains due to the behavior of secondary depositors. Each banker, to protect his ability to meet his obligations when due, will set a minimum value to this ratio below which he does not want to see it fall."

Holmes 1969: (then-Senior Vice President, Federal Reserve Bank, New York): "The idea of a regular injection of reserves - in some approaches at least - also suffers from a naive assumption that the banking system only expands loans after the System (or market factors) have put reserves in the banking system. In the real world, banks extend credit, creating deposits in the process, and look for the reserves later. The question then becomes one of whether and how the Federal Reserve will accommodate the demand for reserves. In the very short run, the Federal Reserve has little or no choice about accommodating that demand; over time, its influence can obviously be felt."

Friedman 1971: "The correct answer for [the question of the origin of] both Euro-dollars and liabilities of U.S. banks is that their major source is a bookkeeper's pen."

Minsky 1975: "A bank is not a money lender that first acquires and then places funds. [...] A bank first lends or invests and then 'finds' the cash to cover whatever cash drains arise."

Moore 1979: "With lagged reserve requirements, once the deposits have been created the central bank has no choice but to make the required reserves available."

Minsky 1986: "Money is unique in that it is created in the act of financing by a bank and is destroyed as the commitments on debt instruments owned by banks are fulfilled. Because money is created and destroyed in the normal course of business, the amount outstanding is responsive to the demand for financing. [...] Banking is not money lending; to lend, a money lender must have money. The fundamental banking activity is accepting, that is, guaranteeing that some party is creditworthy. [...] When a banker vouches for creditworthiness or authorizes the drawing of checks, he need not have uncommitted funds on hand. He would be a poor banker if he had idle funds on hand for any substantial time. In lieu of holding non-income-earning funds, a banker has access to funds. Banks make financing commitments because they can operate in financial 
markets to acquire funds as needed; to so operate they hold assets that are negotiable in markets and hold credit lines at other banks."

Kydland and Prescott 1990: "There is no evidence that either the monetary base or M1 leads the [business] cycle, although some economists still believe this monetary myth. Both the monetary base and M1 series are generally procyclical and, if anything, the monetary base lags the cycle slightly [...]. The fact that the transaction component of real cash balances (M1) moves contemporaneously with the cycle while the much larger non-transaction component (M2) leads the cycle suggests that credit arrangements could play a significant role in future business cycle theory."

Federal Reserve Bank of Chicago 1994: "The actual process of money creation takes place primarily in banks. [...] Checkable liabilities of banks are money. These liabilities are customers' accounts. They increase when customers deposit currency and checks and when the proceeds of loans made by the banks are credited to borrowers' accounts. In the absence of legal reserve requirements, banks can build up deposits by increasing loans and investments so long as they keep enough currency on hand to redeem whatever amounts the holders of deposits want to convert into currency. [...] One of the major responsibilities of the Federal Reserve System is to provide the total amount of reserves consistent with the monetary needs of the economy at reasonably stable prices [...]. Of course, [banks] do not really pay out loans from the money they receive as deposits. If they did this, no additional money would be created. What they do when they make loans is to accept promissory notes in exchange for credits to the borrowers' transaction accounts. Loans (assets) and deposits (liabilities) both rise by [the amount of the loan]."

King 1994: (Governor, the Bank of England, and Chairman, the Monetary Policy Committee, 2003-13): “...In the United Kingdom, money is endogenous - the Bank supplies base money on demand at its prevailing interest rate, and broad money is created by the banking system. The endogeneity of money has caused great confusion, and led some critics to argue that money is unimportant. This is a serious mistake."

White 2002: (Deputy Governor, the Bank of Canada, 1988-94): "Some decades ago, the academic literature would have emphasised the importance of the reserves supplied by the central bank to the banking system, and the implications (via the money multiplier) for the growth of money and credit. Today, it is more broadly understood that no industrial country conducts policy in this way under normal circumstances. Recognising how unstable in practice is the demand for cash reserves, and the associated implications for interest rate volatility, there has been a decisive shift towards the use of short-term interest rates as the policy instrument. In this framework, cash reserves supplied to the banking system are whatever they have to be to ensure that the desired policy rate is in fact achieved."

Bindseil 2004: (Director General of Market Operations, European Central Bank, 2012-19 [now Director General of Market Infrastructure and Payments], ): "It appears that with RPD [Reserve Position Doctrine, i.e. money multiplier view], academic economists developed theories detached from reality, without resenting or even admitting this detachment. Economic variables of very different nature were mixed up and precision in the use of the different concepts (e.g. operational versus intermediate targets, short-term vs. long-term interest rates, reserve market quantities vs. monetary aggregates, reserve market shocks vs. shocks in the money demand, etc.) was often too low to allow obtaining applicable results. The dynamics of academic research and the underlying incentive mechanisms seem to have failed to ensure pressure on academics to 
ensure that models of central bank operations were sufficiently in line with the reality of these operations."

Berry et al. 2007: (The Bank of England Quarterly Bulletin): "When banks make loans, they create additional deposits for those that have borrowed the money."

Goodhart 2007: (Monetary Policy Committee Member, the Bank of England, 1997-2000): “... as long as the Central Bank sets interest rates, as is the generality, the money stock is a dependent, endogenous variable. This is exactly what the heterodox, Post-Keynesians [...] have been correctly claiming for decades, and I have been in their party on this."

Tucker 2007: (Deputy Governor, the Bank of England, 2009-13): “[B]anks [...] in the short run, [...] lever up their balance sheets and expand credit at will. As transactions balances and so the means of exchange in our payments system, the moneyness of bank deposits lies at the core of credit intermediation. Subject only but crucially to confidence in their soundness, banks extend credit by simply increasing the borrowing customer's current account, which can be paid away to wherever the borrower wants by the bank 'writing a cheque on itself'. That is, banks extend credit by creating money. This 'money creation' process is constrained: by their need to manage the liquidity risk - from the withdrawal of deposits and the drawdown of backup lines - to which it exposes them. Adequate capital and liquidity, including for stressed circumstances, are the essential ingredients for maintaining confidence."

Dudley 2009: "The Federal Reserve has committed itself to supply sufficient reserves to keep the fed funds rate at its target. If banks want to expand credit and that drives up the demand for reserves, the Fed automatically meets that demand in its conduct of monetary policy."

Disyatat 2010: "This paper contends that the emphasis on policy-induced changes in deposits is misplaced. If anything, the process actually works in reverse, with loans driving deposits. In particular, it is argued that the concept of the money multiplier is flawed and uninformative in terms of analyzing the dynamics of bank lending."

Freedman 2010: (Deputy Governor, the Bank of Canada, 1988-2003): "It used to be that most academic research treated money (or sometimes base) as the exogenous policy instrument under the control of the central bank. This was an irritant to those of us working in central banks, because the instrument of policy had always been the short-term interest rate, and because all monetary aggregates (beyond base) have always been and remain endogenous. In recent years, more and more academics, in specifying their models, have treated the short-term interest rate as the policy instrument, thereby increasing the usefulness of their analyses [...]."

Goodhart 2010: (Monetary Policy Committee Member, the Bank of England, 1997-2000): “The old pedagogical analytical approach that centred around the money multiplier was misleading, atheoretical and has recently been shown to be without predictive value. It should be discarded immediately."

European Central Bank 2011: (Monthly Bulletin. October 2011): "The money multiplier framework has a long and distinguished pedigree in the literature. Multiplier analysis is based on the assumption that the central bank unilaterally sets the level of the monetary base, i.e. the monetary base is the instrument of monetary policy. The money multiplier then determines the supply of broad money, while short-term interest rates adjust in order to establish equilibrium between money demand and money supply. Clearly, this account contrasts with the way in which monetary policy is, in general, implemented in practice. In fact [...] central banks set an official 
interest rate and then supply the volume of reserves necessary in order to steer short-term market interest rates close to the official interest rate."

Constâncio 2011: (Vice President, the European Central Bank, 2010-18): "It is argued by some that financial institutions would be free to instantly transform their loans from the central bank into credit to the non-financial sector. This fits into the old theoretical view about the credit multiplier according to which the sequence of money creation goes from the primary liquidity created by central banks to total money supply created by banks via their credit decisions. In reality the sequence works more in the opposite direction with banks taking first their credit decisions and then looking for the necessary funding and reserves of central bank money."

Borio 2012: "The banking system does not simply transfer real resources, more or less efficiently, from one sector to another; it generates (nominal) purchasing power. Deposits are not endowments that precede loan formation; it is loans that create deposits."

Demiralp and Carpenter 2012: "The narrow, textbook money multiplier does not appear to be a useful means of assessing the implications of monetary policy for future money growth or bank lending."

European Central Bank 2012: "The occurrence of significant excess central bank liquidity does not, in itself, necessarily imply an accelerated expansion of ... credit to the private sector. If credit institutions were constrained in their capacity to lend by their holdings of central bank reserves, then the easing of this constraint would result mechanically in an increase in the supply of credit. The Eurosystem, however, [...] always provides the banking system with the liquidity required to meet the aggregate reserve requirement. In fact, the ECB's reserve requirements are backward-looking, i.e. they depend on the stock of deposits (and other liabilities of credit institutions) subject to reserve requirements as it stood in the previous period, and thus after banks have extended the credit demanded by their customers."

King 2012: (Governor, the Bank of England, and Chairman, the Monetary Policy Committee, 2003-13): "When banks extend loans to their customers, they create money by crediting their customers' accounts."

Sheard 2013: "[T] he widespread view [is] that banks can "lend out" their reserves (deposits) at the central bank, as if bank reserves represented a pool of money that is just waiting to "flow into" bank lending. [S] uch a thing cannot occur and therefore has not occurred, the point is usually made in reverse. [...] Many talk as if banks can "lend out" their reserves, raising concerns that massive excess reserves created by QE could fuel runaway credit creation and inflation in the future. But banks cannot lend their reserves directly to commercial borrowers, so this concern is misplaced. Banks do need to hold reserves (as a liquidity buffer) against their deposits, and banks create deposits when they lend. But normally banks are not reserve constrained, so excess reserves do not loosen a reserve constraint."

Turner 2013: (Chairman, Financial Services Authority, UK, 2008-13): "Banks do not, as too many textbooks still suggest, take deposits of existing money from savers and lend it out to borrowers: they create credit and money ex nihilo - extending a loan to the borrower and simultaneously crediting the borrower's money account. That creates, for the borrower and thus for real economy agents in total, a matching liability and asset, producing, at least initially, no increase in real net worth. But because the tenor of the loan is longer than the tenor of the deposit - because there is maturity transformation - an effective increase in nominal spending power has been created." 


\section{REFERENCES}

Admati, A., and Hellwig, M. (2012). The bankers' new clothes-What's wrong with banking and what to do about it. Princeton: Princeton University Press.

Alhadeff, D.A. (1954). The Rise of Commercial Banking. Berkeley: University of California Press (reprinted in 1980 by Arno Press as: Monopoly and Competition in Banking).

Allen, F., and Gale, D. (2004a). "Financial intermediaries and markets." Econometrica, 72(4):1023-61.

Allen, F., and Gale, D. (2004b). "Competition and financial stability." Journal of Money, Credit, and Banking, 36(3):453-80.

Aschheim, J. (1959). "Commercial banks and financial intermediaries: fallacies and policy implications." Journal of Political Economy, LXVII: 59-71.

Baltensperger, E. (1980). "Alternative approaches to the theory of the banking firm." Journal of Monetary Economics, 6(1):1-37.

Barrdear, J., and Kumhof, M. (2016). "The macroeconomics of central bank issued digital currencies." Bank of England Working Paper No. 605.

Barontini, C., and Holden, H. (2019). "Proceeding with caution-a survey on central bank digital currency. Bank for International Settlements Papers 101.

Be Duc, L., and Le Breton, G. (2009). "Flow of funds analysis at the ECB-Framework and applications." European Central Bank Occasional Paper 105.

Benes, J., and Kumhof, M. (2012). “The Chicago plan revisited.” International Monetary Fund Working Paper No. 12/202.

Bencivenga, V.R., and Smith, B. (1991). "Financial intermediation and endogenous growth." Review of Economic Studies, 58(2):195-209.

Bernanke, B.S. (November 2006). "Monetary aggregates and monetary policy at the Federal Reserve: A historical perspective." Speech at Fourth ECB Central Banking Conference, Frankfurt, Germany.

Bernanke, B.S., and Blinder, A. (1988). "Credit, money, and aggregate demand." The American Economic Review, 78(2):435-39.

Bernanke, B.S., and Gertler, M. (1995). "Inside the black box: the credit channel of monetary policy transmission." The Journal of Economic Perspectives, 9(4):27-48.

Berry, S., Harrison, R., Thomas, R., and Weymarn, L.D. (2007). "Interpreting movements in broad money." Bank of England Quarterly Bulletin 2007 Q3.

Bindseil, U. (2004). "The operational target of monetary policy and the rise and fall of reserve position doctrine.” European Central Bank Working Papers 372. 
Bindseil, U. (2019). "Central bank digital currency-financial system implications and control." Mimeo.

Borio, C. (2012). "The financial cycle and macroeconomics: What have we learnt?" Bank for International Settlements Working Papers 395.

Bourva, J. (1992). "Money creation and credit multipliers." Review of Political Economy, 4(4):447-66.

Carpenter, S., and Demiralp, S. (2012). "Money, reserves, and the transmission of monetary policy: Does the money multiplier exist?" Journal of Macroeconomics, 34(1):59-75.

Cassel, G. (1918). Theoretische Sozialoekonomie. Leipzig: C. F. Wintersche Verlagshandlung.

Casu, B., Girardone, C., and Molyneux, P. (2006). Introduction to Banking. Harlow: FT Prentice Hall, Pearson Education Ltd.

Cecchetti, S.G. (2008). Money, Banking and Financial Markets (2nd edition). New York: McGraw-Hill Irwin.

Cheng, C., and Werner, R.A. (2015). "An empirical analysis of economic research produced by five major central banks (1988-2008)." Centre for Banking, Finance and Sustainable Development Discussion Paper, University of Southampton.

Constâncio, V. (2011). "Challenges to monetary policy in 2012.” Speech at International Conference on Interest Rates at European Central Bank, December 2011.

Crick, W.F. (1927). “The genesis of bank deposits.” Economica, 191-202.

Culbertson, J. (1958). "Intermediaries and monetary theory: A criticism of the Gurley-Shaw Theory." The American Economic Review, 48(1):119-31.

Currie, L. (1934). "The supply and control of money in the United States," Chapter XV. Harvard University Press.

Davidson, P. (1978). "Why money matters: lessons from a half-century of monetary theory." Journal of Post Keynesian Economics, 1(1):46-70.

Davidson, P. (1993). "The Elephant and the Butterfly: Or Hysteresis and Post Keynesian Economics." Journal of Post Keynesian Economics, 15(3):309-22.

Davoodalhosseini, S.M.R. (2018). "Central bank digital currency and monetary policy.” Bank of Canada Staff Discussion Paper No. 2018-36.

Deutsche Bundesbank (2017). "The role of banks, nonbanks and the central bank in the money creation process.” Monthly Report, Deutsche Bundesbank.

Dewatripont, M., Rochet, J.-C., and Tirole, J. (2010). Balancing the Banks: Global lessons from the financial crisis. Princeton: Princeton University Press.

Diamond, D.W., and Dybvig, P.H. (1983). "Bank runs, deposit insurance, and liquidity." Journal of Political Economy, 91(3):401-19. 
Diamond, D.W., and Rajan, R.G. (2001). "Banks, short-term debt and financial crises: Theory, policy implications and applications." Carnegie-Rochester Conference Series on Public Policy, 54(1):37-71.

Duesenberry, J. (1962). "A process approach to flow-of-funds analysis." In: The Flow-of Funds Approach to Social Accounting: Appraisals, Analysis, and Applications, NBER Chapters, 173-94. National Bureau of Economic Research, Inc.

Douglas, P.H. (1935). Controlling Depressions. New York: W.W. Norton \& Company Inc.

Douglas, P.H., Fisher, I., Graham, F.D., Hamilton, E.J., King, W.I., and Whittlesey, C.R. (1939). A program for monetary reform. Unpublished manuscript.

Engert, W., and Fung, B.S.C. (2017). "Central bank digital currency: motivations and implications." Bank of Canada Staff Discussion Paper No. 2017-16.

European Central Bank (2011). "The supply of money-bank behaviour and the implications for monetary analysis.” ECB Monthly Bulletin, October, 63-79.

European Central Bank (2012). Monthly Bulletin, May.

Fagiolo, G. and Roventini, A. (2016). "Macroeconomic policy in DSGE and agent-based models redux: New developments and challenges ahead.” LEM Papers Series 2016/17, Laboratory of Economics and Management (LEM), Sant'Anna School of Advanced Studies, Pisa, Italy.

FED Chicago (1994). "Modern Money Mechanics. A Workbook on Bank Reserves and Deposit Expansion."

Fernández-Villaverde, J., and Sanches, D. (2016). “Can currency competition work?” NBER Working Paper No. 22157.

Fisher, I. (1936). “100 percent money and the public debt.” Economic Forum, 406-20.

Freedman, C. (2010). "Reflection on three decades at the Bank of Canada." In: Macroeconomics, Monetary Policy, and Financial Stability: A Festschrift in Honour of Charles Freedman.

FSB (2014). “Global Shadow Banking Monitoring Report 2014.” October 2014.

FSB (2017). "Implementation and Effects of the G20 Financial Regulatory Reforms." Third Annual Report. July 3, 2017.

FSB (2019). "Global Monitoring Report on Non-Bank Financial Intermediation 2018." February 4, 2019.

Gertler, M., and Kiyotaki, N. (2011). "Financial intermediation and credit policy in business cycle analysis." In: B. Friedman, and M. Woodford (Eds.), Handbook of Monetary Economics. North Holland: Elsevier. 
Goodfriend, M. (1991). "Money, credit, banking, and payment system policy." Federal Reserve Bank of Richmond Economic Review, 77:7-23.

Goodhart, C.A.E. (2010). "Money, credit and bank behaviour: Need for a new approach." National Institute Economic Review, 214:F73-F82.

Gorton, G., and Pennacchi, G. (1990). "Financial intermediaries and liquidity creation." The Journal of Finance, 45(1):49-71.

Graham, F. (1936). "Partial reserve money and the 100 percent proposal." The American Economic Review, 26(3):428-40.

Graziani, A. (1989). "The theory of the monetary circuit." Thames Papers in Political Economy, 1-26.

Gurley, J.G., and Shaw, E.S. (1955). Financial aspects of economic development. The American Economic Review, 45(4):515-38.

Gurley, J.G., and Shaw, E.S. (1956). "Financial intermediaries and the saving-investment process." The Journal of Finance, 11(2):257-76.

Gurley, J.G., and Shaw, E.S. (1960). Money in a theory of finance. Washington, DC: The Brookings Institution.

Hahn, A.C. (1920). Volkswirtschaftliche Theorie des Bankkredits. Tübingen: J.C.B. Mohr.

Hanson, S.G., Kashyap, A.K., and Stein, J.C. (2011). "A macroprudential approach to financial regulation." Journal of Economic Perspectives, 25(1):3-28.

Harrod, R. (1939). “An essay in dynamic theory.” Economic Journal, 49(193):14-33.

Hawtrey, R.G. (1919). Currency and Credit. London: Longmans, Green and Co.

Hayek, F. (1929). Geldtheorie und Konjunkturtheorie. Hölder-Pichler-Tempsky.

Holmes, A. (1969). "Operational constraints on the stabilization of money supply growth." Controlling Monetary Aggregates, Conference Series 1, FED Boston.

Howe, R.H. (1915). "The Evolution of Banking: A study of the development of the credit system.” Chicago: C. H. Kerr \& Company.

Jakab, Z., and Kumhof, M. (2015). "Banks are not intermediaries of loanable funds - and why this matters." Bank of England Working Paper No. 529.

Kaldor, N. (1982). The Scourge of Monetarism. Oxford: Oxford University Press.

Kashyap, A., Rajan, R., and Stein, J. (2002). "Banks as liquidity providers: An explanation for the coexistence of lending and deposit-taking." The Journal of Finance, 57(1):33-73.

Keynes, J.M. (1924). Tract on Monetary Reform. London: Macmillan and Co.

Keynes, J.M. (1930). A Treatise on Money. London: Macmillan and Co. 
Keynes, J.M. (1936). The General Theory of Employment, Interest and Money. London: Palgrave Macmillan.

King, M. (1994). "Debt deflation: Theory and evidence." European Economic Review, 38(3):419-45.

King, M. (2012). Speech given at the South Wales Chamber of Commerce at the Millennium Centre, Cardiff, October 23, 2012.

Knight, F. (1933). Memorandum on Banking Reform. Franklin D. Roosevelt Presidential Library, Personal File 431.

Krugman, P. (2015). "The rage of the bankers.” The New York Times, September 21, 2015.

Kydland, F.E., and Prescott, E.C. (1990). "Business cycles: Real facts and a monetary myth." FED Minneapolis Quarterly Review, 14(2):3-18.

Lavoie, M. (1992). "Jacques Le Bourva's theory of endogenous credit-money." Review of Political Economy, 4(4):436-446.

Lavoie, M. (2005). "Monetary base endogeneity and the new procedures of the asset-based Canadian and American monetary systems," Journal of Post Keynesian Economics, 27(4):689709.

Lavoie, M. (2014). Post-Keynesian Economics: New Foundations. Cheltenham, UK: Edward Elgar Publishing Ltd.

Lavoie, M., and Godley, W. (2006). "Features of a realistic banking system within a PostKeynesian stock-flow consistent model." In: Setterfield, M. (Ed.), Complexity, Endogenous Money and Macroeconomic Theory: Essays in Honour of Basil J. Moore, 251-68.

LeBaron, B., and Tesfatsion, L. (2008). "Modeling macroeconomies as open-ended dynamic systems of interacting agents." The American Economic Review, 98(2):246-50.

Lutz, F.A. (1939). "Velocity analysis and the theory of the creation of deposits." Economica, 6(22):156-69.

MacLeod, H.D. (1856). The Theory and Practice of Banking (two volumes). London: Longman, Greens and Co.

Mancini-Griffoli, T., Peria, M.S.M., Ari, A., Kiff, J., Popescu, A., and Rochon, C. (2018). "Casting light on central bank digital currency." International Monetary Fund Discussion Note.

Mankiw, N.G. (2010). Macroeconomics, seventh edition. New York: Worth Publishers.

Marshall, A. (1888). Report by the Gold and Silver Commission of 1887.

Marshall, A. (1890). Principles of Economics. London: Macmillan and Co.

McLeay, M., Radia, A., and Thomas, R. (2014a). "Money creation in the modern economy." Bank of England Quarterly Bulletin, 54(1):14-27. 
McLeay, M., Radia, A., and Thomas, R. (2014b). "Money in the modern economy: An introduction." Bank of England Quarterly Bulletin, 54(1):4-13.

Minsky, H. (1960). “The pure theory of banking.” Hyman P. Minsky Archive, Paper 478.

Minsky, H. (1975). "Suggestion for a cash-flow-oriented bank examination." Proceedings of a Conference on Bank Structure and Competition, FED Chicago.

Minsky, H.P. (1978). “The financial instability hypothesis: A restatement.” Hyman P. Minsky Archive, Paper 180, 541-52.

Minsky, H.P. (1986). Stabilizing an Unstable Economy. Yale University Press. Second edition (2008). New York: McGraw-Hill.

Minsky, H.P. (1993). "The financial instability hypothesis.” In: Arestis, P. and Sawyer, M. (Eds.), Handbook of Radical Political Economy. Edward Elgar Publishing Ltd.

Mises, L. von (1912). Theorie des Geldes und der Umlaufsmittel. Leipzig: Duncker und Humblot.

Moeller, H. (1925). Die Lehre vom Gelde. Leipzig: Quelle und Meyer.

Moore, B.J. (1979). “The endogenous money stock.” Journal of Post Keynesian Economics, 2(1):49-70.

Moore, B.J. (1983). "Unpacking the Post Keynesian black box: Bank lending and the money supply." Journal of Post Keynesian Economics, 5(4):537-56.

Moore, B.J. (1986). "How credit drives the money supply: the significance of institutional developments." Journal of Economic Issues, 20(2):443-52.

Myers, S.C., and Rajan, R. G. (1998). "The paradox of liquidity." The Quarterly Journal of Economics, 113(3):733-71.

Phillips, C.A. (1920). Bank Credit. New York: Macmillan and Co.

Ponomarenko, A. (2017). "A note on money creation in emerging market economies." Journal of Financial Economic Policy, 9(1):2-19.

Rajan, R.G. (1998). "The past and future of commercial banking viewed through an incomplete contract lens." Journal of Money, Credit and Banking, 30(3):524-50.

Riordan, M.H. (1993). “Competition and bank performance: a theoretical perspective.” In: C. Mayer and X. Vives (Eds.), Capital markets and financial intermediation, 11:328-43.

Robinson, J. (1956). The Accumulation of Capital. London: Macmillan and Co.

Ryan-Collins, J., Greenham, T., Werner, R., and Jackson, A. (2011). Where does money come from? A guide to the UK monetary and banking system. London: New Economics Foundation.

Samuelson, P. (1948). Economics. New York: McGraw-Hill. 
Samuelson, P., and Nordhaus, W. (1995). Economics. New York: McGraw-Hill.

Sealey, C., and Lindley, J.T. (1977). "Inputs, outputs and a theory of production and cost at depositary financial institutions." Journal of Finance, 32(4):1251-66.

Shapiro, N. (2005). "Competition and aggregate demand." Journal of Post Keynesian Economics, 27(3):541-49.

Sheard, P. (2013). "Repeat after me: Banks cannot and do not 'lend out' reserves." Standard \& Poor's Economic Research.

Schumpeter, J.A. (1912). Theorie der wirtschaftlichen Entwicklung. Berlin: Duncker \& Humblot.

Schumpeter, J.A. (1954). History of Economic Analysis. New York: Oxford University Press.

Simons, H.C. (1934). “A Positive Program for Laissez Faire," University of Chicago Public Policy Pamphlet No. 15.

Simons, H.C. (1936). "Rules versus authorities in monetary policy." Journal of Political Economy, 44(1):1-30.

Smith, W.L. (1959). "Financial intermediaries and monetary controls." The Quarterly Journal of Economics, 73(4):533-53.

Smith, P.F. (1966). "Concepts of money and commercial banks." The Journal of Finance, 21(4):635-48.

Solomon, E. (1959). "Financial institutions in the savings-investment process." Conference on Savings and Residential Financing, 10-55.

Stein, J.C. (2014). "Banks as patient debt investors." American Economic Association/American Finance Association Joint Luncheon speech delivered on January 3, 2014, in Philadelphia, Pennsylvania.

Stiglitz, J. (1997). Economics (second edition). New York: W.W. Norton.

Tesfatsion, L. (2003). "Agent-based computational economics: Modeling economies as complex adaptive systems." Information Sciences, 149(4):262-68.

Tesfatsion, L. (2006a). "Agent-based computational modeling and macroeconomics." In: Colander, D. (Ed.), Post-Walrasian Macroeconomics: Beyond the Dynamic Stochastic General Equilibrium Model, 175-202. Cambridge: Cambridge University Press.

Tesfatsion, L. (2006b). "Agent-based computational economics: A constructive approach to economic theory." In: Tesfatsion, L., and Judd, K. (Eds.), Handbook of Computational Economics, Vol. 2, 16:831-80.

Towers, G. (1939). Minutes of proceedings and evidence respecting the Bank of Canada.

Tucker, P. (2007). "Money and credit: banking and the macroeconomy." Speech at Monetary Policy and the Markets Conference, Bank of England. 
Turner, A. (2013). "Credit, money and leverage: What Wicksell, Hayek and Fisher knew and modern macroeconomists forgot." Stockholm School of Economics Working Paper for Conference "Towards a Sustainable Financial System."

US Treasury (2004). "Sale and issue of marketable book-entry treasury bills, notes, and bonds." Department of the Treasury Circular, Fiscal Service Series No. 1-93. Office of the Federal Register, National Archives and Records Administration.

Vera, A.P. (2001). "The endogenous money hypothesis: some evidence from Spain (1987-1998). Journal of Post Keynesian Economics, 23(3):509-26.

Vymyatnina, Y. (2006). "How much control does Bank of Russia have over money supply?" Research in International Business and Finance, 20(2):131-44.

Werner, R.A. (2005). New paradigm in macroeconomics: solving the riddle of Japanese macroeconomic performance. London: Palgrave MacMillan.

Werner, R.A. (2014). "Can banks individually create money out of nothing? The theories and the empirical evidence." International Review of Financial Analysis, 36:1-19.

Werner, R.A. (2016). "A lost century in economics: Three theories of banking and the conclusive evidence." International Review of Financial Analysis, 46:361-79.

White, W. (2002). "Changing views on how best to conduct monetary policy: the last fifty years.” Speech at Reserve Bank of India.

Whittlesey, C.R. (1944). "Problems of our domestic money and banking system." The American Economic Review, Vol. 34, No. 1, Part 2, Supplement, Papers and Proceedings of the Fifty-Sixth Annual Meeting of the American Economic Association, 245-59.

Wicksell, K. (1898). Geldzins und Gueterpreise: Eine Studie ueber die den Tauschwert des Geldes bestimmenden Ursachen. Jena: Fischer.

Wicksell, K. (1907). "The influence of the rate of interest on prices." Economic Journal, 17:213-20.

Wicksell, K. (1935). Lectures on Political Economy, Volume II: Money. London: George Routledge \& Sons.

Wicksell, K. (1936). Interest and prices-A study of the causes regulating the value of money (original published in 1898, titled Geldzins and Gueterpreise). New York: Sentry Press.

Winkler, B. (2010). "Cross-checking and the flow of funds.” In: Papademos, L., and Stark, J. (Eds.), Enhancing Monetary Analysis, 355-80. European Central Bank.

Withers, H. (1909). The meaning of money. London: Smith, Elder \& Co.

Withers, H. (1918). The business of finance. London: John Murray. 